\title{
Observation-based modelling of permafrost carbon fluxes with accounting for deep carbon deposits and thermokarst activity
}

\author{
T. Schneider von Deimling ${ }^{1,2}$, G. Grosse ${ }^{1}$, J. Strauss ${ }^{1}$, L. Schirrmeister ${ }^{1}$, A. Morgenstern ${ }^{1}$, S. Schaphoff ${ }^{2}$, \\ M. Meinshausen ${ }^{3}$, and J. Boike ${ }^{1}$ \\ ${ }^{1}$ Alfred Wegener Institute, Helmholtz Centre for Polar and Marine Research, Periglacial Research Unit, Potsdam, Germany \\ ${ }^{2}$ Potsdam Institute for Climate Impact Research, Potsdam, Germany \\ ${ }^{3}$ School of Earth Sciences, The University of Melbourne, Victoria, Australia
}

Correspondence to: T. Schneider von Deimling (thomas.schneider@awi.de)

Received: 25 September 2014 - Published in Biogeosciences Discuss.: 5 December 2014

Revised: 25 April 2015 - Accepted: 12 May 2015 - Published: 5 June 2015

\begin{abstract}
High-latitude soils store vast amounts of perennially frozen and therefore inert organic matter. With rising global temperatures and consequent permafrost degradation, a part of this carbon stock will become available for microbial decay and eventual release to the atmosphere. We have developed a simplified, two-dimensional multi-pool model to estimate the strength and timing of future carbon dioxide $\left(\mathrm{CO}_{2}\right)$ and methane $\left(\mathrm{CH}_{4}\right)$ fluxes from newly thawed permafrost carbon (i.e. carbon thawed when temperatures rise above pre-industrial levels). We have especially simulated carbon release from deep deposits in Yedoma regions by describing abrupt thaw under newly formed thermokarst lakes. The computational efficiency of our model allowed us to run large, multi-centennial ensembles under various scenarios of future warming to express uncertainty inherent to simulations of the permafrost carbon feedback.

Under moderate warming of the representative concentration pathway (RCP) 2.6 scenario, cumulated $\mathrm{CO}_{2}$ fluxes from newly thawed permafrost carbon amount to 20 to 58 petagrams of carbon (Pg-C) (68\% range) by the year 2100 and reach 40 to $98 \mathrm{Pg}-\mathrm{C}$ in 2300 . The much larger permafrost degradation under strong warming (RCP8.5) results in cumulated $\mathrm{CO}_{2}$ release of 42 to $141 \mathrm{Pg}-\mathrm{C}$ and 157 to $313 \mathrm{Pg}$ $\mathrm{C}$ (68\% ranges) in the years 2100 and 2300, respectively. Our estimates only consider fluxes from newly thawed permafrost, not from soils already part of the seasonally thawed active layer under pre-industrial climate. Our simulated $\mathrm{CH}_{4}$ fluxes contribute a few percent to total permafrost carbon release yet they can cause up to $40 \%$ of total permafrostaffected radiative forcing in the 21 st century (upper $68 \%$
\end{abstract}

range). We infer largest $\mathrm{CH}_{4}$ emission rates of about $50 \mathrm{Tg}$ $\mathrm{CH}_{4}$ per year around the middle of the 21 st century when simulated thermokarst lake extent is at its maximum and when abrupt thaw under thermokarst lakes is taken into account. $\mathrm{CH}_{4}$ release from newly thawed carbon in wetlandaffected deposits is only discernible in the $22 \mathrm{nd}$ and $23 \mathrm{rd}$ century because of the absence of abrupt thaw processes. We further show that release from organic matter stored in deep deposits of Yedoma regions crucially affects our simulated circumpolar $\mathrm{CH}_{4}$ fluxes. The additional warming through the release from newly thawed permafrost carbon proved only slightly dependent on the pathway of anthropogenic emission and amounts to about $0.03-0.14{ }^{\circ} \mathrm{C}$ (68\% ranges) by end of the century. The warming increased further in the 22nd and 23rd century and was most pronounced under the RCP6.0 scenario, adding 0.16 to $0.39^{\circ} \mathrm{C}$ (68\% range) to simulated global mean surface air temperatures in the year 2300 .

\section{Introduction}

Soils in high northern latitudes represent one of the largest reservoirs of organic carbon in the terrestrial biosphere, holding an estimated 900 to 1700 petagrams (Pg) of organic carbon (Hugelius et al., 2014). While portions of this carbon pool are already affected by seasonal thaw in the active layer, substantial amounts are locked in perennially frozen deposits at depths currently exceeding the seasonal thaw depth. Zimov et al. (2006) have estimated that an amount of $450 \mathrm{Pg}$ $\mathrm{C}$ is stored in deep Siberian organic-rich frozen loess and 
have speculated that this carbon stock could significantly contribute to global carbon fluxes when thawed. A more recent study based on updated observations estimates a total of 211 (58 to 371) Pg-C being stored in ice- and carbon-rich deep deposits in Siberia and Alaska (Strauss et al., 2013). As long as it is frozen in the ground, permafrost organic matter is not part of the active carbon cycle and can be considered mainly inert. With sustained warming and subsequent degradation of deeper permafrost deposits, a part of this carbon pool will become seasonally thawed. Consequently, it will become prone to microbial decomposition and mineralization. By ultimately increasing the atmospheric concentration of the greenhouse gases $\mathrm{CO}_{2}$ and $\mathrm{CH}_{4}$, the carbon release from thawing permafrost regions is considered a potentially large positive feedback in the climate-carbon system (Schaefer et al., 2014; Schuur et al., 2015). Given the long millennial timescale processes leading to the build-up of old carbon in permafrost soils, future rapid releases from these deposits are irreversible on a human timescale.

However, the magnitude and timing of carbon fluxes as a consequence of permafrost degradation are highly uncertain. This is mainly due to incomplete observational knowledge of the amount of organic matter stored in permafrost deposits, of its quality and decomposability, as well as due to the challenge of modelling the full chain of processes from permafrost thaw to carbon release. Furthermore, conceptual and numerical permafrost landscape models also require suitable upscaling methods ranging from local to global scales, based on field-based knowledge of the surface characteristics, key processes and data collection of key parameters (Boike et al., 2012). The vulnerability of permafrost carbon and its fate when thawed will be strongly determined by various environmental controls (Grosse et al., 2011) such as soil type and soil moisture, which both affect soil thermal conductivity and therefore determine the timescale of heat penetration into the ground. Additionally, surface conditions such as organic-rich soil surface layers, vegetation cover and snow exert strong controls on subsurface temperatures by insulating the ground from surface air temperatures (Koven et al., 2013a). In the absence of conditions for abrupt permafrost thaw, mineral permafrost soils are typically more vulnerable to degradation than carbon-rich organic soils. The difference in vulnerability results from the insulating properties of thick organic layers which slow down permafrost degradation (Wisser et al. 2011). Further, the often higher ice-content of organic as compared to mineral soils requires a larger energy input for phase transition, and the usually anaerobic environments in organic soils slow down carbon mineralization. Yet, organic soils which are prone to ground subsidence and impoundment can be highly vulnerable and thus reveal permafrost degradation at increased rates (e.g. Camill et al., 2005; Johnson et al., 2013).

Therefore, for capturing site-specific pathways of carbon release from permafrost degradation, it is important to consider the differing soil environments under which the or- ganic matter will be thawed. Of key importance is the impact of hydrological and redox conditions which determine whether mineralized carbon will be emitted as $\mathrm{CO}_{2}$ or $\mathrm{CH}_{4}$ (Olefeldt et al., 2013). Future changes in hydrological conditions in permafrost regions will therefore crucially affect the high-latitude carbon balance. In particular, regions of ice-rich late Pleistocene deposits (Yedoma) are considered to become potential hot spots for intensive thermokarst lake formation with consequent increases in the fraction of permafrostaffected sediments under anaerobic environments (Walter et al., 2007a). Apart from affecting hydrological conditions, thermokarst lakes also exert a strong warming of sub-lake sediments and thus enhance abrupt permafrost degradation. If thermokarst lake depths exceed the maximum thickness of winter lake ice, these lakes retain liquid water year-round and provide a strong warming and thawing of the underlying sediments (Arp et al., 2012). As a consequence, mean annual temperatures of thermokarst lake-bottom sediments can be up to $10^{\circ} \mathrm{C}$ warmer than mean annual air temperatures (Jorgenson et al., 2010).

So far, permafrost carbon dynamics have not been included in standard climate model projections, possibly due to only recent recognition of the large vulnerable permafrost carbon pool and given the complexity of processes involved. The complexity arises not only from the need to simulate physical changes in soil thermal conditions and phase transitions of water as a consequence of various environmental controls (e.g. interactions among topography, water, soil, vegetation and snow; Jorgenson et al., 2010). It also arises from the challenge of describing the full chain of biogeochemical processes for eventual carbon decomposition in the soils and release to the atmosphere. Therefore, various aspects of permafrost physics and biogeochemistry are only recently being implemented into current global climate models (formulated e.g. in Lawrence and Slater, 2008; Koven et al., 2009, 2013b; Lawrence et al., 2011; Dankers et al., 2011; Schaphoff et al., 2013; Ekici et al., 2014). First modelling results suggest a very large range in predicted soil carbon losses from permafrost regions under scenarios of unmitigated climate change (about 20 to $500 \mathrm{Pg}-\mathrm{C}$ by 2100 , see Schaefer et al. (2014) for an overview). This large range demonstrates the current uncertainty inherent to predictions of the timing and strength of the permafrost carbon feedback.

Yet, these studies are based on models which still miss important mechanisms to capture the full complexity of the permafrost carbon feedback. Grosse et al. (2011) and van Huissteden and Dolman (2012) note that none of the current permafrost models consider the spatially inhomogeneous and potentially rapid degradation of ice-rich permafrost by thermokarst lake formation. This omission of abrupt thaw processes may result in underestimating an important part of anaerobic soil carbon decomposition. Studies have also underlined the importance of considering small scales: not only large Arctic lakes, but also the smaller Arctic thaw ponds, are biological hotspots for the emission of $\mathrm{CO}_{2}$ and $\mathrm{CH}_{4}$ (Abni- 
Table 1. Permafrost model parameters and uncertainties. Some parameters are soil pool specific (MS: mineral soils, ORG: organic soils, Y: Yedoma, RTK: refrozen thermokarst deposits - separated into surface and taberal sediments), some parameters depend on hydrologic conditions (AER: aerobic, WET: wetland anaerobic, TKL: thermokarst lake anaerobic) and some parameters depend on organic matter quality (FAST and SLOW).

\begin{tabular}{|c|c|c|c|c|}
\hline Parameter & Unit & $\begin{array}{l}\text { Default } \\
\text { setting }\end{array}$ & $\begin{array}{l}\text { Uncertainty } \\
\text { range }\end{array}$ & References \\
\hline \multicolumn{5}{|l|}{ Carbon inventory } \\
\hline $\begin{array}{l}\text { Mineral soils (MS) } \\
0-3 \text { m (Orthels \& Turbels) }\end{array}$ & $\mathrm{Pg}-\mathrm{C}$ & 540 & $\pm 40 \%$ & Hugelius et al. (2014) \\
\hline $\begin{array}{l}\text { Organic soils (ORG) } \\
0-3 \text { m (Histels) }\end{array}$ & Pg-C & 120 & $\pm 40 \%$ & Hugelius et. al (2014) \\
\hline $\begin{array}{l}\text { Yedoma (Y) } \\
0-15 \mathrm{~m}\end{array}$ & $\mathrm{Pg}-\mathrm{C}$ & 83 & $\pm 75 \%$ & Strauss et al. (2013) \\
\hline $\begin{array}{l}\text { Refrozen thermokarst deposits } \\
\text { RTK }_{\text {Surface }}(0-5 \mathrm{~m}) \\
\text { RTK }_{\text {Taberal }}(5-15 \mathrm{~m})\end{array}$ & $\mathrm{Pg}-\mathrm{C}$ & $\begin{array}{l}128 \\
114\end{array}$ & $\begin{array}{l} \pm 75 \% \\
\pm 75 \%\end{array}$ & $\begin{array}{l}\text { Strauss et al. (2013) } \\
\text { Walter et al. (2014) }\end{array}$ \\
\hline Fraction fast pool ${ }^{\mathrm{a}}$ & $\%$ & 2.5 & $1-4$ & $\begin{array}{l}\text { Dutta et al. (2006); } \\
\text { Burke et al. (2012); } \\
\text { Schädel et al. (2014) }\end{array}$ \\
\hline Fraction slow pool & $\%$ & 45 & $30-60$ & $\begin{array}{l}\text { Sitch et al. (2003); } \\
\text { Koven et al. (2011); } \\
\text { Burke et al. (2012) }\end{array}$ \\
\hline \multicolumn{5}{|l|}{ Carbon release } \\
\hline $\begin{array}{l}\text { Turnover time of aerobic } \\
\text { slow pool at } 5^{\circ} \mathrm{C}^{\mathrm{b}}\end{array}$ & years & 25 & $10-40$ & $\begin{array}{l}\text { Sitch et al. (2003), } \\
\text { Burke et al. (2012), } \\
\text { Dutta et al. (2006) }\end{array}$ \\
\hline $\begin{array}{l}\text { Ratio of production } \\
\mathrm{CH}_{4}: \mathrm{CO}_{2}^{\text {aerobic }}\end{array}$ & & $1: 50$ & $\pm 50 \%$ & $\begin{array}{l}\text { Lee et al. (2012); } \\
\text { Schuur et al. (2008); } \\
\text { Segers (1998) }\end{array}$ \\
\hline $\begin{array}{l}\text { Ratio of production } \\
\mathrm{CH}_{4}: \mathrm{CO}_{2}{ }^{\text {anaerobic }}\end{array}$ & & $\begin{array}{l}\text { FAST } 1: 1 \\
\text { SLOW } 1: 7\end{array}$ & $\begin{array}{l} \pm 20 \% \\
\pm 50 \% \\
\end{array}$ & $\begin{array}{l}\text { Walter Anthony et al. (2014) } \\
\text { Lee et al. (2012) }\end{array}$ \\
\hline $\mathrm{Q}_{10}$ sensitivity aerobic & & 2.5 & $1.5-3.5$ & $\begin{array}{l}\text { Schädel et al. (2013) } \\
\text { and references therein }\end{array}$ \\
\hline $\mathrm{Q}_{10}$ sensitivity anaerobic & & 3.0 & $2-6$ & Walter and Heimann (2000) \\
\hline $\mathrm{CH}_{4}$ oxidation rate & $\%$ & $\begin{array}{l}\text { TKL } 15 \\
\text { WET } 40\end{array}$ & $\begin{array}{l}10-20 \\
20-60\end{array}$ & $\begin{array}{l}\text { see Burke et al. (2012) } \\
\text { and references therein }\end{array}$ \\
\hline \multicolumn{5}{|l|}{ Permafrost thaw } \\
\hline $\begin{array}{l}\text { Thaw rate (MS, AER) for } \\
\text { warm and cold permafrost } \\
\text { d }\end{array}$ & $\mathrm{cm} \mathrm{yr}^{-1} \mathrm{~K}^{-1}$ & $\begin{array}{l}1.0 \\
0.1\end{array}$ & $\begin{array}{l} \pm 50 \% \\
\pm 50 \%\end{array}$ & $\begin{array}{l}\text { Frauenfeld et al. (2004), } \\
\text { Hayes et al. (2014), } \\
\text { Schaphoff et al. (2013) }\end{array}$ \\
\hline $\begin{array}{l}\text { Scale factor thermal } \\
\text { diffusivity WET : AER }\end{array}$ & & $1 / 3$ & $\pm 30 \%$ & $\mathrm{See}^{\mathrm{e}}$ \\
\hline $\begin{array}{l}\text { Scale factor thermal } \\
\text { diffusivity TKL: AER }\end{array}$ & & 9.3 & $\pm 30 \%$ & Kessler et al. (2012) \\
\hline
\end{tabular}


Table 1. Continued.

\begin{tabular}{|c|c|c|c|c|}
\hline Parameter & Unit & $\begin{array}{l}\text { Default } \\
\text { setting }\end{array}$ & $\begin{array}{l}\text { Uncertainty } \\
\text { range }\end{array}$ & References \\
\hline \multicolumn{5}{|l|}{ Wetland description } \\
\hline $\begin{array}{l}\text { Wetland extent }{ }^{\mathrm{f}} \\
\text { (pre-industrial) }\end{array}$ & $\%$ & $\begin{array}{l}\text { MS } 2 \\
\text { ORG } 60 \\
\text { Y, RTK } 40\end{array}$ & $\begin{array}{l} \pm 50 \% \\
\pm 10 \% \\
\pm 10 \%\end{array}$ & $\begin{array}{l}\text { GLWD, Lehner and Döll } \\
(2004) \\
\text { Burke et al. (2012) }\end{array}$ \\
\hline $\begin{array}{l}\text { maximum increase in wetland extent }{ }^{\mathrm{g}} \\
\text { (above pre-industrial) }\end{array}$ & $\%$ & $\begin{array}{l}\text { MS } 30 \\
\text { ORG, Y, RTK } 10\end{array}$ & $\begin{array}{l} \pm 50 \% \\
\pm 50 \%\end{array}$ & Gao et al. (2013) \\
\hline \multicolumn{5}{|l|}{ Thermokarst description } \\
\hline $\begin{array}{l}\text { Newly formed thermokarst lake fraction } \\
F^{\text {TKLmax }}\end{array}$ & $\begin{array}{l}\% \\
\text { (coverage } \\
\text { per latitude) }\end{array}$ & $\begin{array}{l}\text { MS } 8 \\
\text { ORG } 16 \\
\text { Y } 40 \\
\text { RTK } 25\end{array}$ & $\begin{array}{l} \pm 25 \% \\
\pm 25 \% \\
\pm 25 \% \\
\pm 25 \%\end{array}$ & See the Supplement \\
\hline $\begin{array}{l}\text { High-latitude temperature anomaly } \\
\mathrm{d} T^{\prime \text { TKLmax }} \text { at } F^{\mathrm{TKLmax}}\end{array}$ & ${ }^{\circ} \mathrm{C}$ & 5 & $4-6$ & See the Supplement \\
\hline $\begin{array}{l}{ }^{a} \text { For Yedoma deposits, we assume a doubled labile } \\
\text { carbon with little decomposition in the past (Strauss } \\
\text { thawed over long timescales in the past and are there } \\
{ }^{b} \text { We assume the turnover time of the fast pool to be } \\
{ }^{c} \text { We discard very small ratios of } \mathrm{CH}_{4}: \mathrm{CO}_{2}^{\text {anaerobic }} \\
\text { the initial phase of the incubation. } \\
{ }^{\mathrm{d}} \text { Indicated thaw rates are exemplary for warm and c } \\
\text { the Supplement) by assuming that above-zero tempe } \\
{ }^{\mathrm{e}} \text { We prescribe aggregated thermal diffusivities for } \\
\text { conditions. Based on observational evidence (Romar } \\
\text { latent heat input for thaw of ice-filled pore volumes. } \\
\text { as simulated by Kessler et al. (2012). } \\
{ }^{\mathrm{f}} \text { Based on the GLWD database, Burke et al. (2012) } \\
\text { permafrost deposit extents (Hugelius et al., 2014), w } \\
\text { (MS:ORG:Y:RTK). This results in a total weighted ir } \\
{ }^{\mathrm{g}} \text { The potential for increases in wetland extent in mi } \\
\text { soils is rather small. } \\
{ }^{\mathrm{h}} \text { Early Holocene warming by a few degrees Celsius } \\
\text { rapid and intensive thermokarst activity (Walter et al }\end{array}$ & $\begin{array}{l}\text { action }(5 \pm 3 \%) \text { as } \\
\text { t al., } 2012) \text {. In contr } \\
\text { ore depleted in high- } \\
\text { year. } \\
\text { ferred from incubatic } \\
\text { ld permafrost (corre } \\
\text { tures prevail during } \\
\text { ils under aerobic con } \\
\text { vsky et al., 2010), w } \\
\text { or the thermokarst sc } \\
\text { stimate an area cover } \\
\text { estimate an area we } \\
\text { tial wetland extent o } \\
\text { eral soils is consider }\end{array}$ & $\begin{array}{l}\text { limentation of organic mate } \\
\text { we assume a reduced labil } \\
\text { ality organic matter (Walte } \\
\text { experiments as it is likely tl } \\
\text { nnding to a MAGT of just b } \\
\text { months a year and that thaw } \\
\text { tions and use scale factors t } \\
\text { assume reduced thaw rates } \\
\text { carbon pools, we tuned sca } \\
\text { te of } 9 \% \text { for wetlands and } 3 \\
\text { ting of } 80 \%: 15 \%: 2.5 \% \text { : } \\
\text { bout } 13 \% \text {. } \\
\text { larger than for the other soi } \\
\text { land areas (Kaufman et al. } \\
\text { 2012). }\end{array}$ & $\begin{array}{l}\text { as rather fast and ha } \\
\text { ion in taberal sedim } \\
2007 \mathrm{~b} \text {; Kessler et } \\
\text { se ratios are strongl } \\
\text { and }-10^{\circ} \mathrm{C} \text { ). They } \\
\text { ven by a surface ten } \\
\text { rmine modified ther } \\
\text { wetland pools as w } \\
\text { ctors to reproduce } \\
\text { lakes for all perma } \\
\text { for the permafrost } \\
\text { because the initial } \\
\text { : Velichko et al., } 20\end{array}$ & $\begin{array}{l}\text { d favoured the burial of fresh organic } \\
\text { ents of } 1 \% \text { as these deposits had been } \\
1 ., 2012) \text {. } \\
\text { y affected by a large } \mathrm{CO}_{2} \text { pulse during } \\
\text { were calculated based on Eq. (1) (in } \\
\text { perature warming anomaly of } 1^{\circ} \mathrm{C} \text {. } \\
\text { nal diffusivities under anaerobic } \\
\text { ater-saturated soils require an increased } \\
\text { ong-term behaviour of talik propagation } \\
\text { rost regions. Based on calculated } \\
\text { xtents of our four soil pools } \\
\text { assumed wetland fraction in mineral } \\
\text { 02; Marcott et al., 2013) resulted in }\end{array}$ \\
\hline
\end{tabular}

zova et al., 2012; Laurion, 2010). A recent expert assessment has emphasized the importance of abrupt thaw processes and so far unaccounted carbon stored in deep deposits below $3 \mathrm{~m}$ (Schuur et al., 2013). Evidence for rapid and abrupt thaw on decadal scale is already widespread (Jorgenson et al., 2006; Sannel and Kuhry, 2011; Kokelj et al., 2013; Raynolds et al., 2014), and is likely to increase with future warming, and thus needs to be considered to make realistic projections of carbon dynamics in permafrost regions.

Our study aims to estimate the range of potential carbon fluxes from thawing permafrost by accounting for some abrupt thaw processes which can accelerate the degradation of frozen ground beyond what is inferred by standard modelling approaches that consider gradual thaw. By allocating permafrost organic matter into pools governed by different environmental controls, we describe different pathways of carbon release and we especially account for carbon released as $\mathrm{CH}_{4}$. By explicitly modelling carbon releases from deep carbon stores below $3 \mathrm{~m}$, we contribute to a more complete quantification of the permafrost carbon feedback. Permafrost carbon release from deep deposits has mostly not been taken into account previously, although first-order modelling studies have considered the contribution of permafrost carbon in Yedoma regions (Koven et al., 2011; Schaphoff et al., 2013). Yet in these studies the deep deposits have not contributed significantly to simulated carbon release because the models did not describe abrupt thaw processes which may affect great depths. Khvorostyanov et al. (2008) have inferred a large contribution from Yedoma carbon deposits after the year 2300 when assuming that microbial heat strongly speeds-up permafrost degradation. To the best of our knowledge, our modelling approach is the first to globally quantify the permafrost carbon feedback for the coming centuries while considering carbon release from deep deposits and accounting for abrupt thaw processes.

\section{Multi-pool permafrost model}

Building on previous work (Schneider von Deimling et al., 2012), we have developed a simplified large-scale twodimensional model with parameters tuned to match observed permafrost carbon characteristics. The model calculates per- 
mafrost degradation and eventual $\mathrm{CO}_{2}$ and $\mathrm{CH}_{4}$ release under differing environmental conditions. The newly developed model is briefly described in the following sections; more details are given in the Supplement.

The model accounts for several processes which are crucial to the permafrost carbon feedback:

1. Depending on soil-physical factors, hydrologic conditions and organic matter quality, permafrost carbon inventories were subdivided into a total of 24 pools.

2. Permafrost thaw was calculated for various scenarios of global warming to determine the amount of carbon vulnerable to eventual release. Anaerobic soil fractions were calculated to determine the amount of organic matter stored in wetland- and thermokarst-affected sediments.

3. Permafrost carbon release as either $\mathrm{CO}_{2}$ or $\mathrm{CH}_{4}$ was calculated based on typical rates for aerobic and anaerobic carbon release.

4. By using a simplified climate-carbon model, we have determined the additional increase in global mean temperature through the permafrost carbon feedback.

The computational efficiency of our model allows us to explore the range of simulated permafrost carbon feedbacks by running large ensembles. Our analysis expresses the uncertainty inherent to current knowledge of permafrost carbon release. Our framework allows identification of key model parameters and processes and thus enables us to assess the importance of these factors in affecting the strength and timing of the permafrost carbon feedback.

\subsection{Model structure}

The magnitude and timing of carbon release from thawing permafrost soils will be strongly determined by soil-physical factors such as soil texture and organic matter decomposability, hydrologic state, and surface conditions. To account for these factors, we have developed a simplified but observationally constrained and computationally efficient twodimensional model which allocates permafrost soil organic matter into various carbon pools. These pools describe carbon amount and quality, soil environments, and hydrological conditions (Fig. 1). To account for deposit-specific permafrost carbon vulnerability, we divide our carbon inventory into two near-surface pools (mineral and organic, 0 to $3 \mathrm{~m}$ ) and into two deep-ranging pools (Yedoma and refrozen thermokarst (including taberal sediments), 0 to $15 \mathrm{~m}$, see next section and Table 1). We allocate soil carbon contents according to the inventory estimates of the Northern Circumpolar Soil Carbon Database (Hugelius et al., 2013). Hereby, we describe our mineral soil pool by the sum of soil organic carbon contents from Orthels and Turbels, and our organic pool by the soil organic carbon content from Histels (see the
Supplement for details and for soil classification definitions). We define taberal deposits as permafrost sediments that underwent thawing in a talik (a layer of year-round unfrozen ground in permafrost areas, such as under a deep lake), resulting in diagenetic alteration of sediment structures (loss of original cryostructure, sediment compaction) and biogeochemical characteristics (depletion of organic carbon). In addition, taberal deposits may be subject to refreezing (e.g. after lake drainage; Grosse et al., 2007).

We describe differing hydrological controls by further subdividing each carbon pool into one aerobic fraction and two anaerobic fractions. Hereby we account for anaerobic conditions provided in wetland soils and by water-saturated sediments under thermokarst lakes. We put our model focus on the formation of new thermokarst lakes. We do not consider the contribution of lake areas which existed already under pre-industrial climate. The scarcity of observational data hampers an estimate of circumpolar lake ages. Therefore, estimates of the fraction of sub-lake sediments, which were thawed by past talik formation and growth, are highly uncertain.

In the following we define wetland soils from a purely hydrological viewpoint, i.e. by assuming that these soils are water saturated and not affected by thermokarst. We further assume that anaerobic soil fractions are not stationary but will increase or decrease with climate change.

Therefore, we re-calculate the wetland and thermokarst fraction for each time step (see the Supplement for model details). Given the large-scale dominance of aerobic over anaerobic Arctic landscapes, we assume that wetland or thermokarst-affected soils can be seen as isolated patches surrounded by aerobic soils. Our model describes the expansion of wetlands or thermokarst lakes into aerobic environments by an increase in the anaerobic area fractions at the expense of the aerobic area fraction. Vice versa, a decrease in simulated anaerobic fractions describes the falling dry of previously water-saturated ground and leads to an increase in the aerobic fraction. We do not consider the case of a thermokarst lake which develops into a wetland by terrestrialization. We neither consider the reverse case of a wetland becoming a thermokarst-affected terrain.

The magnitude of fractional area changes determines the amount of carbon which gets transferred between the aerobic and anaerobic pools. Carbon transferred is then subject to environmental control of thaw and decomposition of the corresponding new pool.

We assume a linear increase in wetland extent with global warming with mean maximum increases up to $30 \%$ above pre-industrial wetland extent (see Table 1). We stress that future changes in wetland extent are subject to large uncertainty. While e.g. Gao et al. (2013) investigate future $\mathrm{CH}_{4}$ release from Arctic regions based on simulating future increases in saturated areas, Avis et al. (2011) consider a scenario of a reduction in future areal extent and duration of high-latitude wetlands. 


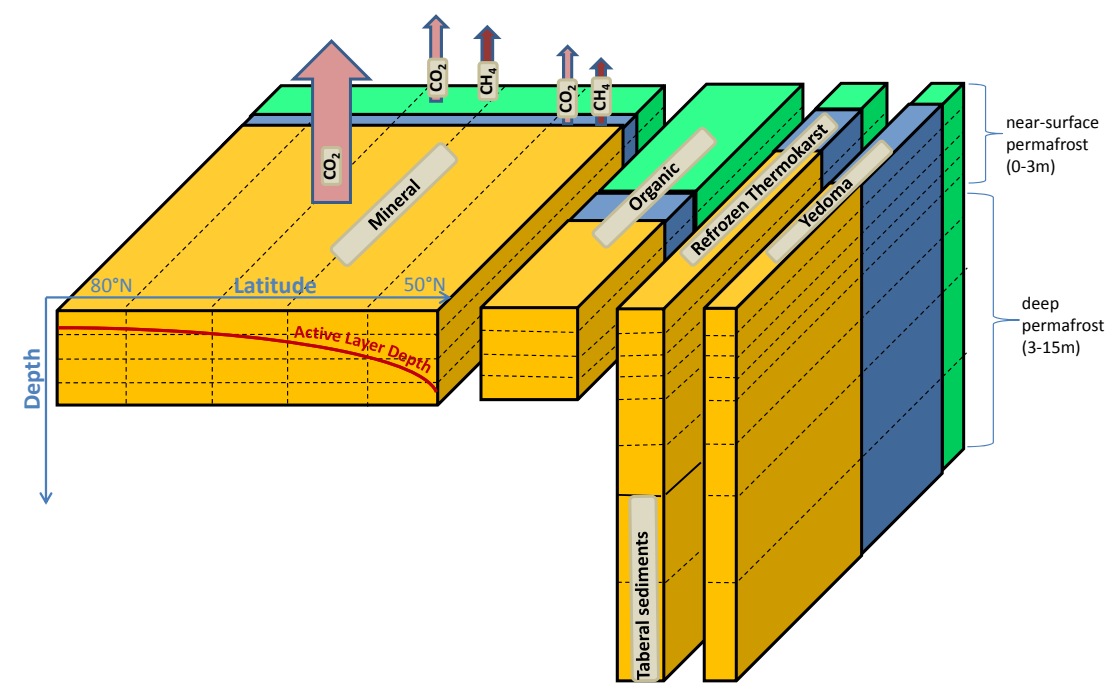

Figure 1. Schematic subdivision of permafrost soil carbon stocks into the four main pools (mineral soils, organic soils, refrozen thermokarst deposits (including taberal), and Yedoma deposits) and into aerobic (dark yellow) and anaerobic (blue: thermokarst lake, green: wetland) fractions. Individual boxes indicate the vertical extent and overall soil carbon quantity, as well as the aerobic and anaerobic fractions (not fully to scale). The dashed lines illustrate the model resolution into latitudinal bands (only shown for the mineral soil carbon pool) and vertical layers. Exemplarily, for the mineral soil carbon pool the north-south gradient of active layer depth (red line) and soil carbon release as $\mathrm{CO}_{2}$ and $\mathrm{CH}_{4}$ are also shown (broad arrows). Not shown is the additional differentiation into a fast and slow pool component.

To capture the growth and decline of newly formed thermokarst lakes, we have developed a conceptual model by making the simplifying assumption that future increases in high-latitude surface air temperatures are the main driver for thermokarst formation. We hereby assume that future warming results in a gradual increase in newly formed thermokarst lake areas (Smith et al., 2005; Plug and West, 2009; Walter et al., 2007b) until a maximum extent is reached (see Table 1). With further warming our model describes a decrease in thermokarst lake extent as we assume that lake drainage is becoming a key factor which strongly limits thermokarst lake area (van Huissteden et al., 2011; Smith et al., 2005; Jones et al., 2011; Morgenstern et al., 2011; see also Fig. S1 in the Supplement).

As the quality of organic matter is a further key determinant for the timescale of carbon release (Strauss et al., 2015) we subdivide the carbon of each individual pool into a fast and a slowly decomposing fraction, with annual or respectively decadal timescales (Table 1). We do not describe permafrost organic matter of low quality (passive pool) which decays on a multi-centennial to millennial timescale. The partitioning of permafrost organic matter results in a total of 24 separate carbon pools which all contribute individually to simulated carbon fluxes (Fig. 1).

All pools and processes are stratified along latitudinal bands that provide a simplified gradient of climate and permafrost types. To describe the climate control exerted by surface-air and ground temperatures in each latitudinal band, we assume that large-scale climate effects can be described by a general north-south temperature gradient. We acknowl- edge that longitudinal patterns can also be pronounced, but with a focus on large-scale regional rather than local changes we expect that the dominant climate control can be described by a profile of coldest permafrost temperatures at the northern limit and warmest temperatures at the southern limit (Romanovsky et al., 2010; Beer et al., 2013). Our model also resolves vertical information to account for varying carbon density with depth and to track active layer changes (see Sect. 2.2). We chose a model resolution of 20 latitudinal bands (which range from 45 to $85^{\circ} \mathrm{N}$ with a $2^{\circ}$ gridding) and of 27 vertical soil layers (corresponding to layer thicknesses of $25 \mathrm{~cm}$ for the upper $4 \mathrm{~m}$, and of $1 \mathrm{~m}$ for the depth range 4 to $15 \mathrm{~m})$.

\subsection{Model initialization}

The flexibility of our model allows us to tune model parameters to observed data, e.g. to permafrost carbon inventories, carbon qualities or active layer depths. This approach assures that our simulations do not suffer from an initial bias in the amount of modelled permafrost carbon. This is contrary to model studies, which fully simulate soil thermal conditions with potentially large biases in initial permafrost extent (Slater and Lawrence, 2013). Such biases result in a large spread in simulated initial permafrost carbon stocks (Mishra et al., 2013; Gouttevin et al., 2012). Based on updated Arctic soil carbon data (Hugelius et al., 2013, 2014; Strauss et al., 2013; Walter Anthony et al., 2014) we allocate permafrost carbon pools (latitudinally and vertically resolved) into different regions: two deep-ranging pools (0 to $15 \mathrm{~m}$ ) in regions 
with Yedoma $(80 \mathrm{Pg}-\mathrm{C})$ and refrozen thermokarst deposits (240 Pg-C), and two near-surface pools (0 to $3 \mathrm{~m}$ ) in remaining regions with mineral soils $(540 \mathrm{Pg}-\mathrm{C})$ and organic soils (120 Pg-C), see the Supplement and Table 1. We describe the vertical soil carbon distribution separately for each metre of near-surface permafrost based on the Northern Circumpolar Soil Carbon Database (Hugelius et al., 2013). For deep soils below $3 \mathrm{~m}$ we assume a constant vertical carbon density (see Strauss et al., 2013, Strauss et al., 2015).

We then initialize each latitudinal band with a mean annual ground temperature between -0.5 and $-10{ }^{\circ} \mathrm{C}$ based on summer air temperature climatology data from the Berkeley Earth data set (http://berkeleyearth.org/data; see the Supplement). The above temperature range is consistent with observed ground temperatures of continuous and discontinuous permafrost in the Northern Hemisphere (Romanovsky et al., 2010). We do not consider permafrost temperatures below $-10^{\circ} \mathrm{C}$ (observed in the Canadian Archipelago and northern Russia) which we consider in the outer tail of permafrost temperature distributions.

By assuming that the equilibrium active layer depth is determined by mean annual ground temperature and by the seasonal cycle of soil temperatures (see Koven et al., 2013a), we calculate typical minimum seasonal thaw depths of about $30 \mathrm{~cm}$ (northernmost permafrost regions) and maximum seasonal thaw of about 250 to $300 \mathrm{~cm}$ (southernmost regions) for present-day climate conditions (see the Supplement). Although topography, soil type, as well as organic layer, vegetation cover, and snow cover variability can lead to spatially very heterogeneous patterns of active layer thicknesses, our scheme describes a latitudinal tendency of a strong northsouth gradient of both subsoil temperature and active-layer thickness that generally matches observations (Beer et al., 2013).

By calculating the active layer depth for each carbon pool and in each latitudinal band, we can determine the fraction of permafrost carbon below the active layer and therefore the amount of organic matter perennially frozen under our baseline climate conditions (i.e. pre-industrial climate). Large amounts of organic matter in permafrost soils reside in the active layer and were affected by past decomposition and release over millennia. It is unclear to what extent the quality of this seasonally thawed organic material will allow extensive microbial decay in the future. Therefore we follow a strategy similar to Burke et al. (2012) and Harden et al. (2012) of considering only the part of permafrost carbon which was locked in perennially frozen ground since pre-industrial times and thus was not part of the active carbon cycle for millennia. We hereby assume that our carbon inventory describes organic matter in continuous and discontinuous permafrost. This carbon is likely to represent organic matter perennially frozen since pre-industrial climate. We do not consider soil carbon stored in younger permafrost deposits (sporadic and isolated patches) which likely had been thawed for the majority of the Holocene and therefore is likely depleted in labile or- ganic matter. When accounting for uncertainty in model parameters, we infer a range of about 400 to $1100 \mathrm{Pg}$ of carbon perennially frozen under pre-industrial climate. By combining field information with modelling, Harden et al. (2012) have estimated a total of about 130 to $1060 \mathrm{Pg}$ of carbon perennially frozen under present-day climate.

Further, we account for the fact that a large part of the permafrost carbon inventory (i.e. the passive pool) will likely be recalcitrant to decay on a multi-centennial timescale (Schmidt et al., 2011). Assuming a passive pool fraction of about 40 to $70 \%$, only about 120 to $660 \mathrm{Pg}$ of permafrost carbon can become vulnerable for eventual carbon release in our simulation setting.

To capture uncertainty in modelled carbon fluxes from thawing permafrost deposits, we have independently sampled a set of 18 key model parameters which are subject to either observational or to model description uncertainty. For each warming scenario, we have performed 500 ensemble runs by applying a statistical Monte Carlo sampling and by assuming uniformly and independently distributed model parameters and initial values.

\subsection{Permafrost thaw and carbon release}

With increasing high-latitude warming the active layer will deepen. We model this process by assuming that climatedriven long-term thaw rates can be described depending on four key factors: physical ground properties, mean annual ground temperatures, depth of the thawed sediment layer, and magnitude of the warming anomaly which drives permafrost degradation (see the Supplement). Hereby we capture factors which strongly affect pool-specific thaw dynamics, e.g. talik formation under thermokarst lakes, dampening of the thaw signal with depth, variable soil-ice contents. We therefore can determine the amount of newly thawed organic matter under various anthropogenic emission scenarios as a consequence of warming above pre-industrial temperatures. We hereby assume carbon emissions proportional to the amount of newly thawed carbon in each pool. Eventual carbon emission as $\mathrm{CO}_{2}$ or $\mathrm{CH}_{4}$ is determined through calculated aerobic and anaerobic emission rates (see the Supplement).

Finally, the permafrost model was coupled to a simple multi-pool climate-carbon cycle model to close the feedback loop: while the permafrost model simulates permafrost degradation and subsequent carbon release (as $\mathrm{CO}_{2}$ and $\mathrm{CH}_{4}$ ), the climate-carbon cycle model calculates atmospheric changes in $\mathrm{CO}_{2}$ and $\mathrm{CH}_{4}$ concentrations and subsequent increases in global mean surface air temperatures. Based on state-of-the-art climate models (CMIP-5, Taylor et al., 2011), we infer polar amplification factors to describe surface air warming in each latitudinal band which then drives permafrost degradation in the next time step. 


\subsection{Model limitations}

Our approach of modelling permafrost thaw relies on the simplifying assumption that the main driver of permafrost degradation is the rise of Arctic air temperatures. Yet soil thermal conditions can be influenced by factors other than temperature (e.g. vegetation cover, snow thickness, topography; Jafarov et al., 2012; Jorgenson et al., 2010). We motivate our modelling approach by focusing on the large-scale and long-term deepening of active layer thickness under various warming scenarios. Although snow cover is considered a key factor for simulating present-day permafrost extent consistent with observations (Koven et al., 2013a; Langer et al., 2013; Osterkamp, 2007; Stieglitz et al., 2003), it is unclear how strongly future changes in high-latitude snow cover will affect permafrost degradation. Given that no highquality data products are available for a circumarctic mapping of snow cover, snow depth and snow density - and given that climate models simulate strongly divergent pathways of future snowfall - we here make the simplifying assumption that the long-term evolution of permafrost is largely driven by changes in surface air temperatures. Similarly, our simplified approach of describing thermokarst dynamics is based on the assumption that future thermokarst formation is largely affected by increasing surface air temperature. Temperature-unrelated, local factors (such as topography, precipitation changes or wildfire) can also be key determinants for thermokarst dynamics. We understand our approach mainly as quantifying carbon fluxes under different hypotheses of future thermokarst development rather than providing deterministic and explicit predictions of individual thermokarst terrains. An alternative scenario of a reduction in high-latitude inland water surface area under future warming was e.g. investigated by Krinner and Boike (2010).

Nutrient limitation in the soils and abrupt carbon release after wildfires are considered two additional and potentially important mechanisms for the carbon balance of thawed permafrost deposits which we do not consider in our model design (Koven et al., 2015; Mack et al., 2004; Turetsky et al., 2011). Probably the largest effect of unaccounted processes on our simulated carbon fluxes comes from the omission of high-latitude vegetation dynamics. Increased carbon uptake in a warmer climate through more productive vegetation can strongly affect the Arctic carbon balance (Schaphoff et al., 2013). The capturing of this feedback component requires the implementation of a dynamic vegetation model which is beyond the scope of this study. Also of importance in this respect is the potential restoration of carbon sinks after lake drainage which could, in the long-term, partially compensate for high $\mathrm{CH}_{4}$ emission (van Huissteden and Dolman, 2012; Kessler et al., 2012; Jones et al., 2012; Walter Anthony et al., 2012).

Our simulated wetland $\mathrm{CH}_{4}$ fluxes describe $\mathrm{CH}_{4}$ produced from newly thawed permafrost carbon. Yet the full carbon balance of wetlands is rather complex and possibly more af- fected by future changes in soil moisture, soil temperature and vegetation composition than by the delivery of newly thawed organic matter through permafrost degradation (Olefeldt et al., 2013). The accounting of these additional factors requires the implementation of comprehensive wetland models (such as suggested by Frolking et al., 2001; Kleinen et al., 2012; Eliseev et al., 2008).

\section{Model results}

\subsection{Permafrost degradation}

We have run our model under various scenarios of future warming, ranging from moderate (RCP2.6) to extensive (RCP8.5). Under RCP2.6, global greenhouse gas emissions peak by 2020 and decline strongly afterwards. We simulate subsequent increases in global mean surface air temperatures which are constrained to below two degrees above preindustrial levels. In the case of unmitigated climate change (RCP8.5), global mean surface air temperatures continuously increase and reach $10^{\circ} \mathrm{C}$ by the end of the $23 \mathrm{rd}$ century at the upper range of our simulations. This pronounced difference in simulated surface air temperatures results in strongly differing pathways of long-term permafrost degradation (Fig. 2).

Depending on initial mean annual ground temperatures (MAGTt0), we infer for cold (MAGTt $\left.0=-10^{\circ} \mathrm{C}\right)$, medium $\left(\operatorname{MAGTt} 0=-5^{\circ} \mathrm{C}\right)$ and warm $\left(\mathrm{MAGTt} 0=-0.5^{\circ} \mathrm{C}\right)$ permafrost mean active layer depths of 20,70 and $250 \mathrm{~cm}$, respectively. In a recent study, Koven et al. (2013a) have diagnosed observed active layer depths north of $55^{\circ} \mathrm{N}$ from a circumpolar and a Russian data set (CALM, Brown et al., 2000; Zhang et al., 2006). Their analysis suggests a range of measured present-day active layer depths ranging from 30 to $230 \mathrm{~cm}$. The authors underline the challenge of comparing modelled with observed active layer depths given the different spatial coverage of models and observations.

As projections of surface air temperatures only start to diverge strongly after the middle of the 21 st century, continuous but slow deepening of the active layer is similar under RCP2.6 and RCP8.5 until 2050 (Fig. 2). We first focus on active layer deepening of the largest pool of permafrost carbon, i.e. organic matter in mineral soils under aerobic conditions (Fig. 2, upper panels). Under moderate warming (RCP2.6), active layer depths stabilize after 2100 for cold and medium permafrost temperatures (blue and green curves). Permafrost in southerly warm regions will degrade in our simulations with the disappearance of near-surface ( 0 to $3 \mathrm{~m}$ ) permafrost before 2100 (red curve). Under strong warming (RCP8.5), a sharp increase in thawing rates in the second half of the 21st century can be seen and the majority of model runs suggest a degradation of near-surface permafrost towards the end of the century. In northern and cold permafrost regions, a complete disappearance of near-surface permafrost is only real- 

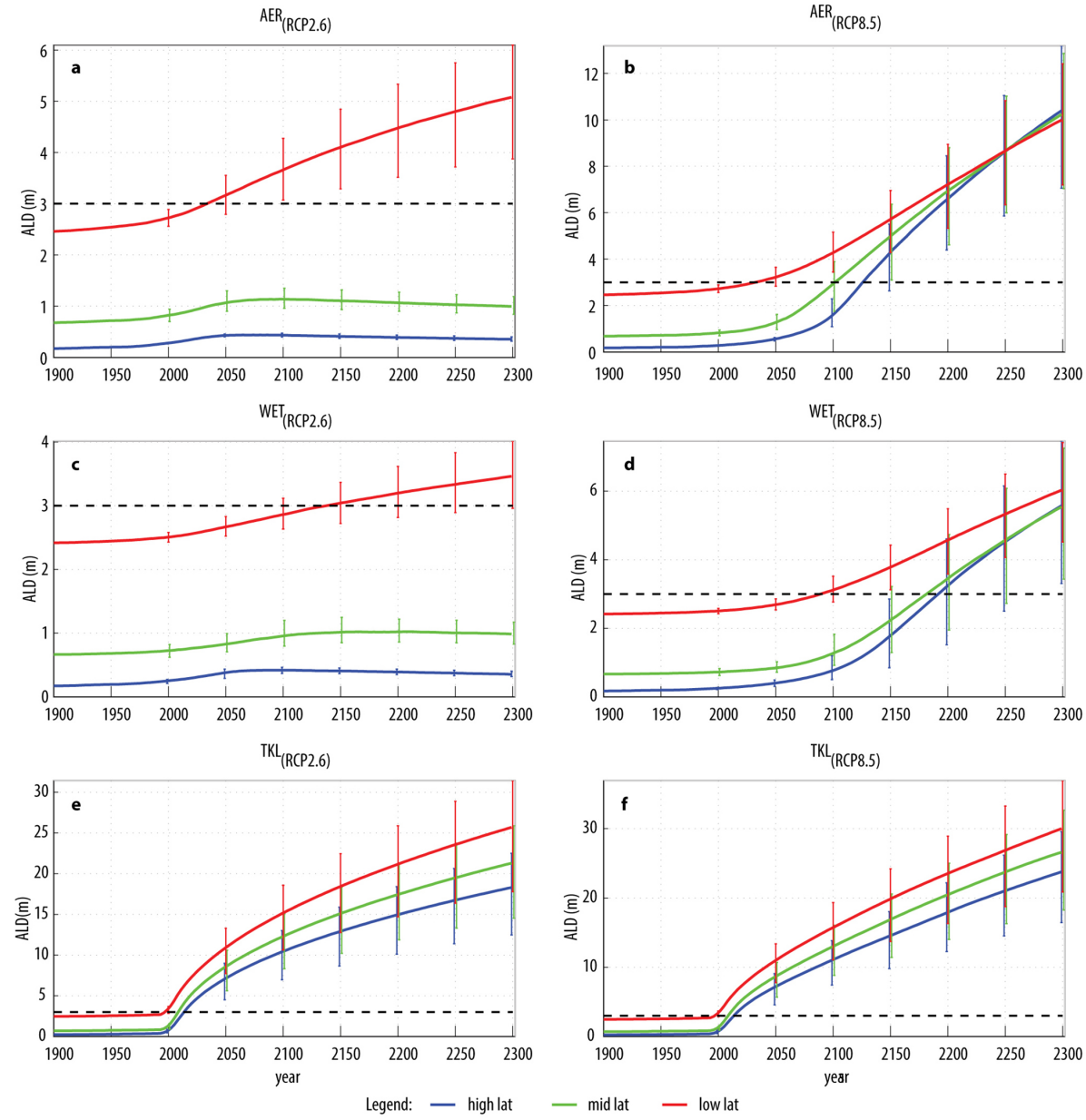

Figure 2. Simulated changes in active layer depths (ALDs) for mineral soils under moderate (RCP2.6) and extensive (RCP8.5) warming (left and right panels). Shown is the deepening of the active layer from the year 1900 until 2300 for a north-south gradient of different initial permafrost temperatures (blue: MAGTt $0=-10^{\circ} \mathrm{C}$, green: MAGTt $0=-5^{\circ} \mathrm{C}$, red: MAGTt $0=-0.5^{\circ} \mathrm{C}$ ) and for different hydrologic conditions (a, b: aerobic, $\mathbf{c}, \mathbf{d}$ : wetland, e, f: thermokarst lake). We assume that newly formed lakes reach the critical depth which prevents winter refreeze by the year 2000 . Vertical bars illustrate the model spread inferred from an ensemble of 500 runs ( $68 \%$ range). The horizontal dashed lines denote the near-surface permafrost boundary $(3 \mathrm{~m})$. Note the different $y$-axis scales.

ized after 2150 (blue curve, upper right panel). The sustained long-term warming leads to a continuous deepening of the permafrost table which can reach about $10 \mathrm{~m}(\sim 7$ to $13 \mathrm{~m}$, $68 \%$ range) by the year 2300 in our simulations.

Under wetland conditions (i.e. water/ice-saturated sediments), the active layer shows a similar but slower deepening in response to rising surface air temperatures (Fig. 2, mid panels). In contrast, when considering thermokarst lake formation, thaw rates increase sharply (Fig. 2, lower panels) once lakes have reached a critical depth which prevents winter refreeze. As we do not model lake depth expansion we assume that formation of new thermokarst lakes is initiated for any warming above pre-industrial climate, while we assume that critical lake depths are only realized with the beginning of the 21st century (see the Supplement). In the first years after intense thermokarst formation, sub-lake talik progression is very pronounced and annual thaw rates amount to many decimetres - in line with observational and modelling studies (Ling et al., 2012; Kessler et al., 2012). The abrupt thaw dynamics results in disappearance of nearsurface permafrost well before 2050 (Fig. 2, lower panels). By the year 2100, typical talik depths amount to 10 to $15 \mathrm{~m}$. The evolution of active layer depths in thermokarst-affected deposits does not strongly differ between moderate and extensive warming (Fig. 2, lower panels). This is because the degradation in thermokarst-affected sediments is driven by lake-bottom temperatures. Averaged over a full year, lakebottom temperatures do not strongly differ between moderate and strong surface air warming (see also Boike et al. (2015) and the Supplement).

In our model setting, we explicitly account for permafrost carbon in deep inventories (Yedoma and refrozen 
thermokarst deposits). By the end of the 23rd century, typical depths of the permafrost table in these carbon- and ice-rich sediments reach about 5 to $9 \mathrm{~m}$ under the RCP8.5 scenario if no abrupt thaw is considered (not shown). Thus even under strong surface air warming, our simulations suggest that a large part of the deep carbon deposits will remain perennially frozen over the coming centuries if only gradual thaw is considered. In contrast, in most latitudes where ice-rich Yedoma is affected by new thermokarst formation, thaw reaches the maximum model depth of $15 \mathrm{~m}$ before 2300 .

\subsection{Permafrost carbon release}

We define permafrost carbon fluxes similar to Burke et al. (2012) and Harden et al. (2012) as the release from newly thawed permafrost carbon, i.e. the contribution of perennially frozen soil organic matter which becomes part of the active carbon cycle if warmed above pre-industrial temperatures. We stress that these fluxes do not describe the full carbon balance of permafrost regions which is also affected by changes in vegetation uptake, new carbon inputs into deeper soil layers and carbon release from soil surface layers which were already seasonally thawed under pre-industrial climate (see discussion in Sect. 2.2).

Depending on the degree of ground warming and thus on the extent of active layer deepening, differing amounts of newly thawed carbon will be made available for microbial decomposition and eventual release to the atmosphere. Figure 3 illustrates permafrost carbon thaw and emissions under a scenario of moderate warming (RCP2.6, upper panels) and extensive warming (RCP8.5, lower panels). Under RCP2.6, largest increases in newly thawed permafrost carbon (Fig. 3, first column) are realized until the middle of the 21 st century with a total of $167 \mathrm{Pg}-\mathrm{C}$ (113 to $239 \mathrm{Pg}-\mathrm{C}, 68 \%$ range) of which 40 to $70 \%$ is assumed part of the passive carbon pool and thus recalcitrant on the timescale considered here. In contrast, the pronounced and continuous warming under RCP8.5 results in much larger amounts of newly thawed permafrost carbon. By the year 2100, 367 Pg-C are thawed (233 to $497 \mathrm{Pg}-\mathrm{C}, 68 \%$ range), and through further permafrost degradation in the $22 \mathrm{nd}$ and 23 rd century, a total of $564 \mathrm{Pg}-\mathrm{C}$ (392 to $734 \mathrm{Pg}-\mathrm{C}, 68 \%$ range) of organic matter is newly thawed by the year 2300 . Focusing on the top $3 \mathrm{~m}$ of soil and considering a larger uncertainty spread in the permafrost carbon inventory, two recent studies estimated a min-max range of 75 to $870 \mathrm{Pg}$ (Burke et al. 2012) and of 105 to $851 \mathrm{Pg}$ (Harden et al. 2012) of newly thawed permafrost carbon under RCP8.5 until the year 2100 .

The intensity of carbon release after permafrost thaw differs strongly among the scenarios in our simulations (Fig. 3). While under RCP2.6, maximum annual $\mathrm{CO}_{2}$ emission rates are constrained to about $0.4 \mathrm{Pg}_{-} \mathrm{C} \mathrm{yr}^{-1}\left(0.2\right.$ to $0.6 \mathrm{Pg}_{-} \mathrm{C} \mathrm{yr}^{-1}$, $68 \%$ range), peak emission rates under RCP8.5 amount to 1.7 $\mathrm{Pg}-\mathrm{C} \mathrm{yr}^{-1}$ (median) and can reach 2.6 $\mathrm{Pg}_{-} \mathrm{C} \mathrm{yr}^{-1}$ (upper $68 \%$ range). The decline in emission rates in the 22 nd and
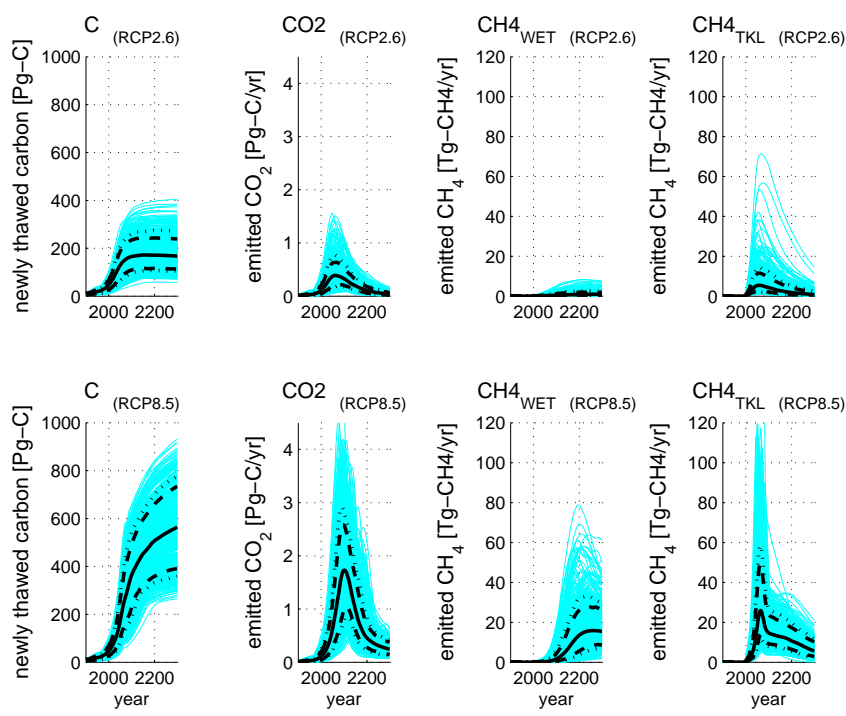

Figure 3. Simulated increase in newly thawed permafrost carbon $\mathrm{C}$ and resulting rates of annual $\mathrm{CO}_{2}$ and $\mathrm{CH}_{4}$ release under moderate (upper panels) and extensive (lower panels) global warming for the years 1900 to $2300 . \mathrm{CH}_{4}$ release is shown separately for fluxes from wetlands (WET) and newly formed thermokarst lakes (TKLs). Blue lines show ensemble simulation results based on 500 model runs which account for parameter uncertainty. Black lines show statistical quantiles (solid line: median; dashed lines: $68 \%$ range; dotted lines: $80 \%$ range). Shown are contributions aggregated over all individual pools, summed over all latitudes and depths layers.

23rd century describes the depletion of thawed permafrost carbon through release to the atmosphere. Under all RCPs, peak $\mathrm{CO}_{2}$ emission rates occur around the end of the 21st century.

Due to much lower anaerobic $\mathrm{CH}_{4}$ as compared to aerobic $\mathrm{CO}_{2}$ production rates (Table 1), and due to the majority of soil carbon being thawed under aerobic conditions, emission from thawing permafrost soils amounts to only a few percent of total permafrost carbon release. Observational and modelling experts have estimated that $\mathrm{CH}_{4}$ will contribute by about 1.5 to $3.5 \%$ to future permafrost carbon release (Schuur et al., 2013).

Given the slow progression of permafrost thaw in wetlandaffected sediments, $\mathrm{CH}_{4}$ release from newly thawed permafrost carbon is only discernible after the end of this century (Fig. 3). We consider our estimates of wetland carbon fluxes to be conservative: we neither account for carbon release from organic matter contained in the active layer which is already thawed since pre-industrial times, nor do we account for enhanced thaw of water-saturated grounds affected by non-conductive heat flow.

Our simulations suggest maximum annual $\mathrm{CH}_{4}$ emission rates of a few $\mathrm{Tg}_{-} \mathrm{CH}_{4}$ for moderate warming, about $16 \mathrm{Tg}$ $\mathrm{CH}_{4}$ (8 to $28 \mathrm{Tg}-\mathrm{CH}_{4}, 68 \%$ range) for strong warming. To the contrary, abrupt thaw under thermokarst lakes results in peak $\mathrm{CH}_{4}$ emission after the middle of this century. Under 
Table 2. Cumulated carbon fluxes and increase in global average surface temperature through newly thawed permafrost in the years 2050 , 2100, 2200 and 2300. Median and 68\% ranges (in brackets) were calculated from an ensemble of 500 model runs which account for parameter uncertainty.

\begin{tabular}{|c|c|c|c|c|c|}
\hline & & 2050 & 2100 & 2200 & 2300 \\
\hline \multicolumn{6}{|l|}{$\mathrm{RCP} 2.6$} \\
\hline Cumulated $\mathrm{CO}_{2}$ & {$[\mathrm{Pg}-\mathrm{C}]$} & $17(8-29)$ & $36(20-58)$ & $56(35-89)$ & $64(40-98)$ \\
\hline Cumulated $\mathrm{CH}_{4}$ & {$\left[\mathrm{Tg}-\mathrm{CH}_{4}\right]$} & $173(85-354)$ & $446(218-921)$ & $818(410-1753)$ & 1035 (539-2236) \\
\hline $\mathrm{d} T(\mathrm{PF})$ & {$\left[{ }^{\circ} \mathrm{C}\right]$} & $0.03(0.01-0.05)$ & $0.06(0.03-0.10)$ & $0.10(0.06-0.15)$ & $0.11(0.06-0.18)$ \\
\hline \multicolumn{6}{|l|}{$\mathrm{RCP} 4.5$} \\
\hline Cumulated $\mathrm{CO}_{2}$ & {$[\mathrm{Pg}-\mathrm{C}]$} & $18(9-32)$ & $54(28-92)$ & $118(75-180)$ & 155 (104-216) \\
\hline Cumulated $\mathrm{CH}_{4}$ & {$\left[\mathrm{Tg}-\mathrm{CH}_{4}\right]$} & $227(109-466)$ & $1126(538-2356)$ & 3117 (1657-5969) & 4705 (2592-8449) \\
\hline $\mathrm{d} T(\mathrm{PF})$ & {$\left[{ }^{\circ} \mathrm{C}\right]$} & $0.03(0.01-0.05)$ & $0.08(0.05-0.14)$ & $0.16(0.10-0.25)$ & $0.19(0.13-0.29)$ \\
\hline \multicolumn{6}{|l|}{ RCP6.0 } \\
\hline Cumulated $\mathrm{CO}_{2}$ & {$[\mathrm{Pg}-\mathrm{C}]$} & $18(8-30)$ & $60(29-101)$ & $156(103-224)$ & $193(134-270)$ \\
\hline Cumulated $\mathrm{CH}_{4}$ & {$\left[\mathrm{Tg}-\mathrm{CH}_{4}\right]$} & $201(97-407)$ & $1270(663-2440)$ & $3104(1818-5372)$ & $4615(2664-7778)$ \\
\hline $\mathrm{d} T(\mathrm{PF})$ & {$\left[{ }^{\circ} \mathrm{C}\right]$} & $0.03(0.01-0.05)$ & $0.08(0.04-0.13)$ & $0.18(0.11-0.29)$ & $0.24(0.16-0.39)$ \\
\hline \multicolumn{6}{|l|}{ RCP8.5 } \\
\hline Cumulated $\mathrm{CO}_{2}$ & {$[\mathrm{Pg}-\mathrm{C}]$} & $20(9-36)$ & $87(42-141)$ & $194(136-270)$ & $228(157-313)$ \\
\hline Cumulated $\mathrm{CH}_{4}$ & {$\left[\mathrm{Tg}-\mathrm{CH}_{4}\right]$} & $333(154-665)$ & $1474(836-2614)$ & $3592(2141-6093)$ & 5877 (3644-9989) \\
\hline $\mathrm{d} T(\mathrm{PF})$ & {$\left[{ }^{\circ} \mathrm{C}\right]$} & $0.03(0.02-0.05)$ & $0.09(0.05-0.14)$ & $0.14(0.10-0.21)$ & $0.16(0.11-0.23)$ \\
\hline
\end{tabular}

RCP2.6, maximum annual $\mathrm{CH}_{4}$ emissions are constrained to about $5.5 \mathrm{Tg}_{-} \mathrm{CH}_{4}$ (up to $11.5 \mathrm{Tg}-\mathrm{CH}_{4}$ for the upper $68 \%$ range), while under $\mathrm{RCP} 8.5$ peak $\mathrm{CH}_{4}$ emissions reach about $26 \mathrm{Tg}^{-} \mathrm{CH}_{4}$ (14 to $49 \mathrm{Tg}-\mathrm{CH}_{4}, 68 \%$ range). The strong decline in emission rates towards the end of the century is an expression of the sharp decrease in thermokarst lake extents through increasing drainage under sustained warming (see Fig. S1 in the Supplement).

Under strong warming, our modelled $\mathrm{CH}_{4}$ emissions accumulate to 836 to $2614 \mathrm{Tg}-\mathrm{CH}_{4}$ (68\% range) until the year 2100. Maximum contributions until the year 2300 can reach $10000 \mathrm{Tg}-\mathrm{CH}_{4}$ (upper $68 \%$ range, see Table 2).

We have additionally analysed the impact of uncertainty in initial MAGT distribution on the calculated carbon fluxes. Soil temperatures affect the magnitude of carbon release in two ways. First, MAGTs determine the initial active layer profile and thus the amount of carbon perennially frozen under pre-industrial climate. Second, soil temperatures determine the vulnerability of permafrost carbon to future degradation. Based on a model ensemble with sampling solely uncertainty in MAGT, we inferred a spread in the year 2100 of $32.5 \pm 23$ and $81.5 \pm 8 \% \mathrm{Pg}-\mathrm{C}$ for the scenarios RCP2.6 and RCP8.5 respectively, which further increase to $60 \pm 33$ and $235 \pm 6 \% \mathrm{Pg}-\mathrm{C}$ in the year 2300 . The factor of 3-5 larger fractional uncertainty for the climate mitigation scenario (RCP2.6) illustrates the enhanced sensitivity to initial permafrost temperatures of modelled carbon fluxes under moderate warming.

\subsection{Contribution of individual soil pools and of deep deposits}

Carbon release discussed in the previous section describes the sum of fluxes over all individual soil types, hydrologic controls, and organic matter qualities (based on a total of 24 individual carbon pools, see Sect. 2.1). We illustrate the contribution of individual fluxes to the total carbon budget in Figs. S2 and S3 in the Supplement. It can be seen that $\mathrm{CO}_{2}$ fluxes are largely controlled by contributions from mineral soils, as these soils describe the largest source of organic matter and as they are dominated by aerobic conditions (Fig. S2 in the Supplement). In contrast, the total $\mathrm{CH}_{4}$ balance is influenced by contributions from all soils types. In our simulation setting, 21 st century $\mathrm{CH}_{4}$ fluxes are largely controlled by the formation and expansion of new thermokarst lakes, while discernible $\mathrm{CH}_{4}$ release from newly thawing permafrost in wetlands results only in the 22nd and 23rd century.

We account for a total of $230 \mathrm{Pg}$ of organic carbon buried below $3 \mathrm{~m}$ in Yedoma and refrozen thermokarst deposits (including taberal sediments). Under aerobic or wetland conditions, our simulations suggest only small contributions of these deep deposits to the total release of newly thawed permafrost carbon even under scenarios of strong warming (Fig. 4, Figs. S2 and S3 in the Supplement). Discernible contributions are only inferred towards the end of our simulations (23rd century), with fluxes from deep deposits contributing a maximum of about $10 \%$ to accumulated $\mathrm{CO}_{2}$ release or about $5 \%$ to total wetland $\mathrm{CH}_{4}$ release (upper $68 \%$ 

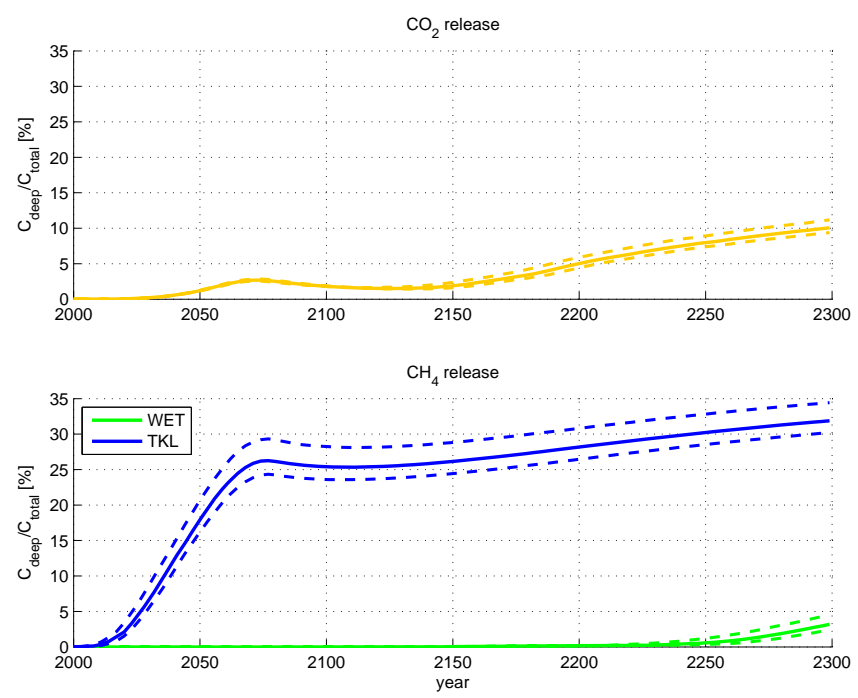

Figure 4. Contribution of deep permafrost carbon deposits to total carbon fluxes under aerobic (upper panel) and anaerobic (lower panel) conditions. Shown is the contribution of cumulated $\mathrm{CO}_{2}$ and $\mathrm{CH}_{4}$ fluxes from deep deposits (3 to $15 \mathrm{~m}$ ) to total circumarctic carbon release ( 0 to $15 \mathrm{~m}$ ) under strong warming (RCP8.5). Solid lines represent median values, dashed lines $68 \%$ ranges. The contribution of deep deposits to wetland-affected $\mathrm{CH}_{4}$ release (green) and to thermokarst-affected $\mathrm{CH}_{4}$ release (blue) is shown separately.

ranges). The lagged response of deep carbon release is an expression of the slow penetration of heat into the ground. In most latitude bands under the RCP2.6 scenario, no frozen carbon from deep deposits is thawed as the moderate warming does not result in active layer depths exceeding $3 \mathrm{~m}$.

Yet if abrupt thaw under thermokarst lakes is accounted for, the fast propagation of sub-lake taliks can unlock large amounts of perennially frozen deep organic matter even within this century (see Figs. S2 and S3 in the Supplement). Our simulations suggest that until 2100 about 25 to $30 \%$ of emitted $\mathrm{CH}_{4}$ from thermokarst lakes stems from contributions of deep permafrost carbon (Fig. 4, lower panel). Maximum contributions until 2300 can amount to $35 \%$ (upper $68 \%$ range).

We have performed additional model simulations to illustrate the extent to which our simulated permafrost carbon fluxes are affected by changes in anaerobic soil fractions and by deep carbon release. For this purpose we have run two further model ensembles under identical parameter settings for each warming scenario in which we (1) fixed anaerobic soil fractions at initial values (i.e. static anaerobic soil fractions), and (2) disregarded soil carbon below $3 \mathrm{~m}$. Resulting $\mathrm{CO}_{2}$ fluxes reveal a comparable magnitude under the different simulation settings because our simulated changes in anaerobic soil fractions and contributions from deep carbon deposits only slightly affect total $\mathrm{CO}_{2}$ release. Yet these factors were found to exert a strong control on simulated $\mathrm{CH}_{4}$ release (Fig. S4 in the Supplement). In particular, $\mathrm{CH}_{4}$ re- lease in the 21 st century is largely driven by the contribution from newly formed thermokarst lakes, enhanced by carbon release from deep deposits.

\subsection{Permafrost-affected warming}

To disentangle the warming caused by anthropogenic greenhouse gas emission from warming caused by permafrost carbon release, we have performed paired simulations under identical parameter settings - once with the permafrost module activated and once deactivated. The difference in global mean surface air temperatures between each pair of ensemble simulations is what we define as the additional global warming caused by newly thawed permafrost carbon (i.e. permafrost-affected warming).

Although permafrost carbon release increases strongly with rising global temperatures (Fig. 3), our results suggest a permafrost-affected global warming of about 0.05 to $0.15^{\circ} \mathrm{C}$ (68\% range) until 2100 which is only slightly dependent on the anthropogenic emission pathway. (Fig. 5, Table 2). The quasi path-independency of the permafrost temperature feedback is an expression of the decreasing radiative efficiency under high atmospheric greenhouse gas levels. Long-term warming from the release of newly thawed permafrost carbon can add an additional $0.4{ }^{\circ} \mathrm{C}$ (upper $68 \%$ range) to global temperatures until the year 2300 . Despite $\mathrm{CH}_{4}$ release contributing only a few percent to total permafrost carbon release, our analyses suggest that it can cause up to about $40 \%$ (upper $68 \%$ range) of permafrost-affected warming. In the 22 nd and 23rd century the radiative balance is largely affected by aerobic permafrost carbon release as emitted $\mathrm{CO}_{2}$ accumulates over centuries in the atmosphere - in contrast to the fast decline in $\mathrm{CH}_{4}$ anomalies with a typical $\mathrm{CH}_{4}$ lifetime of about a decade.

\section{Discussion and conclusions}

This paper presents a new observation-based model for assessing long-term climatic consequences of permafrost degradation. Our simulation strategy consisted in partitioning carbon inventories into different pools of varying soil and surface conditions to model site-specific carbon release. Rather than trying to capture permafrost carbon dynamics in detail, we instead have aimed at describing in a simplified manner a multitude of processes which are key to permafrost carbon release - such as abrupt thaw in thermokarst-affected sediments. We have especially aimed at accounting for the contribution of carbon release from known deep deposits in the 1.3 million $\mathrm{km}^{2}$ large Yedoma region of Siberia and Alaska (Strauss et al., 2013; Walter Anthony et al., 2014), which had been neglected in most previous modelling studies. Our computationally efficient model has enabled us to scan the large uncertainty inherent to observing and modelling the permafrost carbon feedback. In our study we had 

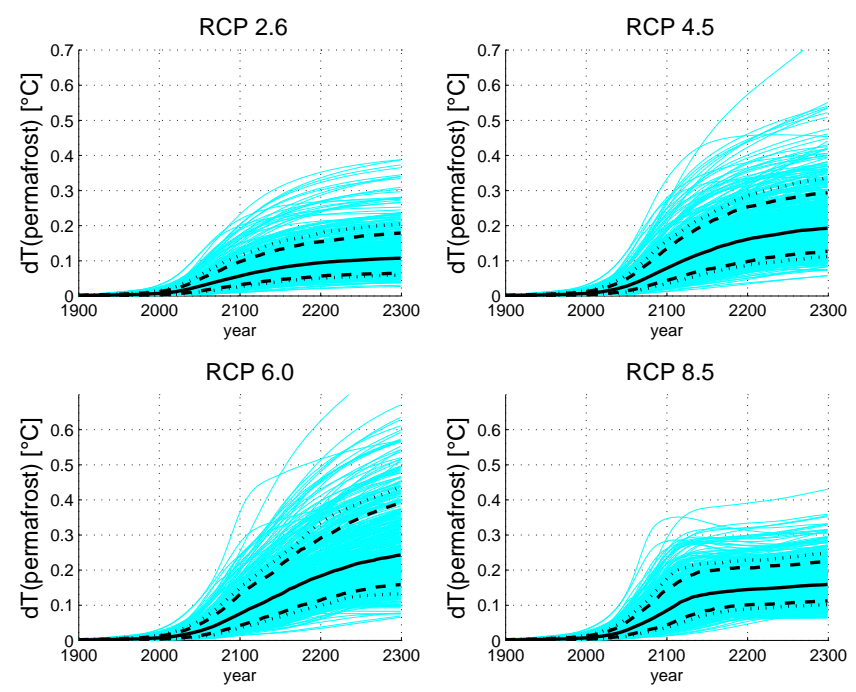

Figure 5. Increase in global average surface air temperature through newly thawed permafrost carbon under various anthropogenic warming scenarios (RCP2.6 to RCP8.5). Blue lines show ensemble simulation results based on 500 model runs which account for parameter uncertainty. Black lines show statistical quantiles (solid line: median; dashed lines: $68 \%$ range; dotted lines: $80 \%$ range). Shown is the temperature feedback as a consequence of $\mathrm{CO}_{2}$ and $\mathrm{CH}_{4}$ release from all individual pools.

focused on the contribution of newly thawed permafrost carbon which becomes vulnerable through soil warming above pre-industrial temperatures. However, we stress that the full permafrost carbon feedback is also affected by carbon fluxes from sources not considered in this study, such as the contribution from soil surface layers (seasonally thawed active layer) and changes in high-latitude vegetation. With rising soil temperatures, further contributions will also result from known carbon stocks in permafrost regions, which are not classified as Gelisols (e.g. histosols). Finally, abrupt thaw processes other than thermokarst (e.g. caused by wildfires, coastal and thermal erosion) not considered in our study will potentially result in enhanced permafrost carbon fluxes (Grosse et al., 2011).

The large spread in future carbon release from permafrost degradation inferred from modelling studies (see Schaefer et al. (2014) and Schuur et al. (2015) for an overview) is caused by various factors. One key issue relates to the pronounced differences in the strength of simulated permafrost degradation. In a recent observationally constrained model study, Hayes et al. (2014) suggest a mean deepening of the active layer of $6.8 \mathrm{~cm}$ over the period 1970 to 2006 . We simulate a deepening by 5.9 to $15.5 \mathrm{~cm}$ ( $68 \%$ range) over the same period when focusing on our mineral soil pool under aerobic conditions. By the year 2100, our simulations suggest a mean active layer deepening of this pool by 40 to $76 \mathrm{~cm}$ under RCP2.6, and of 105 to $316 \mathrm{~cm}$ under RCP8.5. The latter range covers a large part of previous estimates, although some studies suggest lower values (Schaefer et al., 2014). Yet a comparison of aggregated simulated active layer depths should be considered with care as differences in definitions (e.g. of the considered permafrost domain and its vertical extent) or different assumptions of future warming can lead to estimating systematically lower or higher active layer depths.

Our simulations suggest that permafrost emissions will be strongly constrained when limiting global warming: under a climate mitigation pathway (RCP2.6), the increase in high-latitude temperatures results in a moderate deepening of the active layer which stabilizes in most latitudes after the year 2100 (in line with diagnostics based on complex models; Slater and Lawrence, 2013). Until the end of the century about $36 \mathrm{Pg}$ ( 20 to $58 \mathrm{Pg}, 68 \%$ range) of carbon was released as $\mathrm{CO}_{2}$. Under strong warming (RCP8.5), permafrost degradation proves substantial and cumulated $\mathrm{CO}_{2}$ emissions reached $87 \mathrm{Pg}-\mathrm{C}$ ( 42 to $141 \mathrm{Pg}-\mathrm{C}, 68 \%$ range) by the year 2100. A release of $87 \mathrm{Pg}-\mathrm{C}$ corresponds to a mean loss of about $12 \%$ of our initial inventory of $750 \mathrm{Pg}$ of carbon perennially frozen under pre-industrial climate. Other modelling studies have estimated a loss of 6 to $33 \%$ of initial permafrost carbon stocks, while the majority of models suggest a loss of 10 to $20 \%$ (Schaefer et al., 2014). Incubation of permafrost soil samples suggest a carbon loss from mineral soils under aerobic conditions of 13 and $15 \%$ over 100 years when assuming thaw during 3 months in a year (Schädel et al. 2013; Knoblauch et al. 2013).

Our analyses have shown a large potential of reducing uncertainty in simulated carbon fluxes especially for climate mitigation pathways when more and spatially higher resolved data of present-day permafrost temperatures will be available.

Based on our conceptual model of thermokarst lake formation and drainage, our results suggest that abrupt thaw can unlock large amounts of frozen carbon within this century. We infer a deepening of the permafrost table by several metres in 100 years after thermokarst initiation, with additional talik propagation large enough to fully thaw sediments to our lower pool boundary $(15 \mathrm{~m})$ in the second half of the 22nd century. Subsequent $\mathrm{CH}_{4}$ release from newly thawed permafrost under RCP8.5 results in emissions that peak at about $50 \mathrm{Tg}-\mathrm{CH}_{4}$ per year (upper $68 \%$ range) in the 21 st century. A pronounced spike in $\mathrm{CH}_{4}$ emissions as a consequence of rapidly expanding and subsequently shrinking thermokarst lake areas is in line with hypotheses of past rapid thermokarst lake formation and expansion. Walter et al. (2007a) suggest an annual $\mathrm{CH}_{4}$ release of 30 to $40 \mathrm{Tg}-\mathrm{CH}_{4}$ from thermokarst lakes to partially explain $\mathrm{CH}_{4}$ excursions of early Holocene atmospheric $\mathrm{CH}_{4}$ levels. Brosius et al. (2012) discuss a yearly contribution from thermokarst lakes of $15 \pm 4 \mathrm{Tg}-\mathrm{CH}_{4}$ during the Younger Dryas and $25 \pm 5 \mathrm{Tg}_{-} \mathrm{CH}_{4}$ during the Preboreal period.

Our modelled total $\mathrm{CH}_{4}$ fluxes under strong warming are comparable in magnitude to an estimated current release of $24.2 \pm 10.5 \mathrm{Tg}_{-}-\mathrm{CH}_{4}$ per year from northern lakes (Wal- 
ter et al., 2007b). The majority of our results suggest that $\mathrm{CH}_{4}$ fluxes from newly thawed permafrost carbon are an order of magnitude smaller than the contribution from all current natural (about $200 \mathrm{Tg}-\mathrm{CH}_{4} \mathrm{yr}^{-1}$ ) and anthropogenic (about $350 \mathrm{Tg}-\mathrm{CH}_{4} \mathrm{yr}^{-1}$ ) sources (Environmental Protection Agency (EPA), 2010). Focusing on thermokarst lakes in icerich deposits (i.e. on Yedoma and refrozen thermokarst deposits), we infer 21 st century averaged median emission rates of $6.3 \mathrm{Tg}_{-} \mathrm{CH}_{4} \mathrm{yr}^{-1}$ which are about double compared to a recent estimate based on a stochastic thaw-lake model for Siberian ice-rich deposits (van Huissteden et al., 2011). Using an integrated Earth system model framework, Gao et al. (2013) estimate that increases in $\mathrm{CH}_{4}$ emissions until 2100 from inundated area expansion and soil warming range between 5.6 to $15.1 \mathrm{Tg}_{-} \mathrm{CH}_{4} \mathrm{yr}^{-1}$. In contrast to our analyses, their simulated $\mathrm{CH}_{4}$ fluxes are largely dominated by wetland $\mathrm{CH}_{4}$ release because they assume a fixed value of 3.35 for the wetland:lake ratio in regions north of $45^{\circ}$. Even under assumptions of maximum increases in saturated areas, Gao et al. (2013) simulate future thermokarst lake extents which cover only a few percent of Arctic landscapes. In our model setting (see Table 1), we have investigated the scenario of a potential large transformation of northern landscapes, considering up to $50 \%$ of ice-rich regions being affected by newly formed thermokarst lakes - and therefore we simulate a much larger $\mathrm{CH}_{4}$ contribution from permafrost sediments affected by thermokarst.

Burke et al. (2012) infer 21st century annual $\mathrm{CH}_{4}$ emission rates from permafrost wetlands and lakes below $53 \mathrm{Tg}$ $\mathrm{CH}_{4}$ for the majority of their model runs. Although our $\mathrm{CH}_{4}$ release estimates, which are inferred by an independent modelling approach, are comparable in magnitude with recent work, a direct comparison with studies extrapolating observed $\mathrm{CH}_{4}$ fluxes (e.g. van Huissteden et al., 2011; Gao et al., 2011) should be considered with care. Observed $\mathrm{CH}_{4}$ fluxes describe the full carbon balance, including contributions from soil surface layers and vegetation cover, which we do not consider in our model setting.

In contrast to abrupt thaw and fast release under thermokarst lakes, $\mathrm{CH}_{4}$ release from newly thawed carbon in wetland-affected soils is slow with discernible contributions only in the 22 nd and 23 rd century. Although contributing only a few percent to total permafrost carbon release, our simulated $\mathrm{CH}_{4}$ fluxes from newly thawed permafrost carbon can cause up to $40 \%$ of permafrost-affected warming in the 21 st century. Given the short lifetime of $\mathrm{CH}_{4}$, the radiative forcing from permafrost carbon in the 22nd and 23rd century is largely dominated by aerobic $\mathrm{CO}_{2}$ release.

Under strong warming, our modelled $\mathrm{CH}_{4}$ emissions from newly thawed permafrost accumulate to some thousand $\mathrm{Tg}$ until the year 2100 , with maximum contributions of $10000 \mathrm{Tg}_{-} \mathrm{CH}_{4}$ (upper $68 \%$ range) until the year 2300 (see Table 1). Yet the release of this amount of $\mathrm{CH}_{4}$ would only slightly affect future atmospheric $\mathrm{CH}_{4}$ levels under projected $\mathrm{RCP} \mathrm{CH}_{4}$ emissions as the anthropogenic contribution will dominate atmospheric $\mathrm{CH}_{4}$ concentrations. Based on a carbon mass balance calculation of $\mathrm{CH}_{4}$ release from Siberian thermokarst lakes, Walter et al. (2007b) suggest a contribution of about $50000 \mathrm{Tg}-\mathrm{CH}_{4}$ (or 50 to $100 \mathrm{Tg}_{-} \mathrm{CH}_{4} \mathrm{yr}^{-1}$ over centuries) in the extremely unlikely case of a complete thaw of the Yedoma deposits.

To put into relation the contribution of carbon fluxes from deep deposits to the total, circumpolar release from newly thawed permafrost, we have analysed the contribution of individual pools. Our simulations suggest that the omission of deep carbon stocks is unlikely to strongly affect $\mathrm{CO}_{2}$ release from permafrost degradation in the coming centuries. In contrast, $\mathrm{CH}_{4}$ fluxes from newly thawed permafrost are strongly influenced by carbon release from organic matter stored in deep deposits. Although our considered deep pools cover only about $12 \%$ of the total area of Northern Hemisphere Gelisols, and despite the organic matter in these pools being buried deep in the ground, these pools contribute significantly to the total $\mathrm{CH}_{4}$ balance because abrupt thaw under thermokarst lakes can unlock a large portion of previously inert organic matter. About a quarter of 21st century thermokarst lake $\mathrm{CH}_{4}$ release stems from newly thawed organic matter stored in deep deposits (i.e. from soil layers deeper than $3 \mathrm{~m}$ ). Further, our analyses revealed that the release from mineralization of labile organic matter contributes disproportionately highly to these fluxes. Despite assuming a fast (labile) pool fraction of only a few percent, our simulated $\mathrm{CH}_{4}$ fluxes from newly thawed labile organic matter account for up to half of the total thermokarst-affected deep $\mathrm{CH}_{4}$ release in the 21 st century. Therefore, improved observational estimates of the share of labile organic matter would help to reduce uncertainty in simulated $\mathrm{CH}_{4}$ release from deep carbon deposits (Strauss et al., 2015). The analysis of individual deep pools revealed a $\mathrm{CH}_{4}$ release from refrozen thermokarst up to twice the emission from unaltered Yedoma.

Our results suggest a mean increase in global average surface temperature of about $0.1^{\circ} \mathrm{C}$ by the year $2100(0.03$ to $0.14{ }^{\circ} \mathrm{C}, 68 \%$ ranges) caused by carbon release from newly thawed permafrost soils. Long-term warming through the permafrost carbon feedback (year 2300) can add an additional $0.4{ }^{\circ} \mathrm{C}$ (upper $68 \%$ range) to projected global mean surface air temperatures.

Our analyses suggest that the permafrost-induced additional warming is similar under different scenarios of anthropogenic emissions - despite the largest carbon release from permafrost degradation under strong warming. The weak path dependency is a consequence of the decreasing radiative efficiency of emitted permafrost carbon under increasing background $\mathrm{CO}_{2}$ and $\mathrm{CH}_{4}$ concentrations.

In a previous study (Schneider von Deimling et al., 2012; referred to as SvD2012 in the following) the authors calculated carbon fluxes from degradation of near-surface permafrost based on a model which described permafrost dynamics in less detail but was coupled to a more comprehensive description of climate-carbon cycle feedbacks 
(MAGICC-6, Meinshausen et al., 2011). The various differences in model description between SvD2012 and our current study (SvD2015) affect simulated permafrost carbon fluxes and the inferred temperature feedback in multiple ways. In contrast to SvD2012, we now resolve vertical model levels and account for depth-dependent thaw dynamics and carbon distribution. This allows us to better initialize our model based on observed active layer profiles and soil carbon concentrations. As a consequence of our improved thaw rate parametrization (see Sect. 2.2 of the Supplement), in our new study we simulate increased permafrost thaw (compared to SvD2012), especially under moderate warming. Therefore, we now generally simulate larger carbon fluxes in the 21st century which are also due to an improved tuning of soil carbon decomposition. Yet in our current study, we model smaller cumulated carbon fluxes in the 22nd and 23rd century under RCP8.5 because we consider a smaller fraction of permafrost carbon being available for long-term release.

The quantification of additional warming through permafrost carbon release requires a model description of translating permafrost carbon fluxes into atmospheric concentrations of $\mathrm{CO}_{2}$ and $\mathrm{CH}_{4}$, and ultimately into global mean temperature anomalies. In SvD2012, these calculations were based on the MAGICC-6 model (Meinshausen et al., 2011), while in our current study we use a more simplified description based on Allen et al. (2009, see Supplement Sect. 2.5). Finally, the use of a fully fledged carbon cycle emulation (MAGICC-6) in SvD2012 results in additional carbon fluxes from non-permafrost terrestrial and oceanic sources which are triggered by additional warming through permafrost degradation - and thus increase the overall temperature feedback. Differences in estimates of permafrost affected warming between SvD2012 and SvD2015 illustrate that factors independent from permafrost dynamics (such as differing model formulations of ocean heat uptake) do affect the strength of the inferred temperature feedback.

MacDougall et al. (2012) also modelled a permafrost carbon feedback largely independent of the emission pathway but inferred larger upper estimates of permafrost-affected warming due to considering a much larger pool available for carbon release triggered by permafrost degradation. An increase in the permafrost temperature feedback with global warming was inferred by Burke et al. (2012) who considered a much larger spread in the near-surface permafrost carbon inventory ( $~ 300$ to $1800 \mathrm{Pg}-\mathrm{C})$ and who estimated the permafrost temperature feedback by the year 2100 as 0.02 to $0.11^{\circ} \mathrm{C}$ and 0.08 to $0.36^{\circ} \mathrm{C}(90 \%$ ranges $)$ under RCP 2.6 and RCP8.5 respectively.

In conclusion, our results demonstrate that deep carbon deposits and abrupt thaw processes, such as provided by thermokarst lake formation, should be included in future model simulations for an improved representation of the permafrost carbon feedback.

\section{Outlook}

We consider our estimates conservative because carbon release from further, in this study unaccounted sources, are likely to increase the strength of the full permafrost carbon feedback.

1. Our study focuses solely on the carbon fluxes resulting from newly thawed soils and deposits in our simulation scenarios, thus excluding carbon fluxes from permafrost-affected soils in the current active layer. These soils will also warm to different levels under RCP scenarios and very likely will be subject to enhanced mineralization of the large already seasonally thawed $\mathrm{C}$ pool of about $500 \mathrm{Pg}$ (Hugelius et al., 2014).

2. We do not account for the contribution of newly thawed organic matter of low quality, which we assume recalcitrant on the timescale considered here (i.e. 40 to $70 \%$ of thawed organic matter is not available for release). More data and longer time series of incubation experiments, in combination with modelling work of soil carbon dynamics, are needed to better constrain timescale assumptions for soil organic matter decomposition. Also of importance are improved data-based estimates of $\mathrm{CH}_{4}: \mathrm{CO}_{2}$ anaerobic production ratios, which determine the share of carbon emitted as $\mathrm{CH}_{4}$.

3. We do not account for the presence, and potential thaw and mobilization of deep frozen carbon outside the Yedoma and refrozen thermokarst region. Currently no coherent data are available on the distribution and organic carbon characteristics of soils and sediments below $3 \mathrm{~m}$ depth for large regions in Siberia, Alaska and Canada. Our model results suggest that these depths will be affected by thaw over the coming centuries and available thawed organic matter would contribute to the permafrost carbon feedback.

4. We do not consider carbon release from degrading submarine permafrost which might result in an underestimation of circumpolar permafrost-affected $\mathrm{CH}_{4}$ fluxes in our study (Shakhova et al., 2010).

5. Extensive permafrost degradation can support a large and abrupt release of fossil $\mathrm{CH}_{4}$ from below the permafrost cap based on the presence of regional hydrocarbon reservoirs and geologic pathways for gas migration (Walter Anthony et al., 2012). We do not consider this pathway of potentially abrupt $\mathrm{CH}_{4}$ release which could lead to a non-gradual increase in the permafrost carbon feedback if sub-cap $\mathrm{CH}_{4}$ increases non-linearly with warming. Likely, the most important omission in our study stems from changes in the high-latitude carbon balance caused by altered vegetation dynamics. Here, an increased carbon uptake through more productive highlatitude vegetation and the renewal of carbon sinks in 
drained thermokarst basins can considerably decrease the net carbon loss on centennial timescales (Schaphoff et al., 2013; van Huissteden et al., 2011). Yet this loss can be partially compensated through enhanced respiration of soil surface organic matter which is stored in large amounts in permafrost regions (but which was not incorporated into permafrost in the past and thus is not considered in this study). On the other hand, a transition from tundra- towards taiga-dominated landscapes as a consequence of high-latitude warming can strongly decrease surface albedo and therefore additionally warm permafrost regions. We consider the implementation of high-latitude vegetation dynamics into permafrost models a key step towards an improved capturing of the timing and strength of the full permafrost carbon feedback.

\section{The Supplement related to this article is available online at doi:10.5194/bg-12-3469-2015-supplement.}

Acknowledgements. Special thanks to S. Mathesius for the analysis of CMIP-5 data, G. Hugelius for providing soil carbon data for near-surface permafrost inventories, M. Allen for having provided an earlier version of the climate carbon cycle model, $\mathrm{H}$. Lantuit for discussing aspects of permafrost degradation through coastal erosion, C. Schädel for discussing incubation results of soil carbon lability, and K. Walter Anthony and H. Lee for discussing ratios of $\mathrm{CH}_{4}$ versus carbon dioxide production rates.

This study was supported by the Federal Environment Agency for Germany (UBA) under project UFOPLAN FKZ 371241106 and ERC Starting Grant \#338335.

J. Strauss was supported by a grant of the Studienstiftung des deutschen Volkes (German National Academic Foundation), the German Federal Ministry of Education and Research (Grant 01DM12011) and the Initiative and Networking Fund of the Helmholtz Association (\#ERC-0013). A. Morgenstern was supported by the Helmholtz Postdoc Programme of the Initiative and Networking Fund of the Helmholtz Association (\#PD-003). M. Meinshausen was supported by the Australian Research Council grant ARC FT130100809.

Edited by: A. Ito

\section{References}

Abnizova, A., Siemens, J., Langer, M., and Boike, J.: Small ponds with major impact: The relevance of ponds and lakes in permafrost landscapes to carbon dioxide emissions, Global Biogeochem. Cy., 26, GB2041, doi:10.1029/2011GB004237, 2012.

Arp, C. D., Jones, B. M., Lu, Z., and Whitman, M. S.: Shifting balance of thermokarst lake ice regimes across the Arctic Coastal Plain of northern Alaska, Geophys. Res. Lett., 39, L16503, doi:10.1029/2012GL052518, 2012.
Avis, C. A., Weaver, A. J., and Meissner, K. J.: Reduction in areal extent of high-latitude wetlands in response to permafrost thaw, Nature Geosci, 4, 444-448, 2011.

Beer, C., Fedorov, A. N., and Torgovkin, Y.: Permafrost temperature and active-layer thickness of Yakutia with 0.5-degree spatial resolution for model evaluation, Earth Syst. Sci. Data, 5, 305-310, doi:10.5194/essd-5-305-2013, 2013.

Boike, J., Langer, M., Lantuit, H., Muster, S., Roth, K., Sachs, T., Overduin, P., Westermann, S., and McGuire, A. D.: Permafrost Physical Aspects, Carbon Cycling, Databases and Uncertainties, in: Recarbonization of the Biosphere, edited by: Lal, R., Lorenz, K., Hüttl, R. F., Schneider, B. U., and von Braun, J., Springer Netherlands, 159-185, 2012.

Boike, J., Kattenstroth, B., Abramova, K., Bornemann, N., Chetverova, A., Fedorova, I., Fröb, K., Grigoriev, M., Grüber, M., Kutzbach, L., Langer, M., Minke, M., Muster, S., Piel, K., Pfeiffer, E. M., Stoof, G., Westermann, S., Wischnewski, K., Wille, C., and Hubberten, H. W.: Baseline characteristics of climate, permafrost and land cover from a new permafrost observatory in the Lena River Delta, Siberia (1998-2011), Biogeosciences, 10, 2105-2128, doi:10.5194/bg-10-2105-2013, 2013.

Boike, J., Georgi, C., Kirilin, G., Muster, S., Abramova, K., Fedorova, I., Chetverova, A., Grigoriev, M., Bornemann, N., and Langer, M.: Physical processes of thermokarst lakes in the continuous permafrost zone of northern Siberia - observations and modeling (Lena River Delta, Siberia), Biogeosciences Discuss., 12, 6637-6688, doi:10.5194/bgd-12-6637-2015, 2015.

Brosius, L. S., Walter Anthony, K. M., Grosse, G., Chanton, J. P., Farquharson, L. M., Overduin, P. P., and Meyer, H.: Using the deuterium isotope composition of permafrost meltwater to constrain thermokarst lake contributions to atmospheric methane during the last deglaciation, J. Geophys. Res. Biogeosci., 117, G01022, doi:10.1029/2011JG001810, 2012.

Brown J., Hinkel K. M., and Nelson F. E.: The circumpolar active layer monitoring (calm) program: research designs and initial results, Polar Geogr, 24, 166-258, 2000.

Burke, E. J., Hartley, I. P., and Jones, C. D.: Uncertainties in the global temperature change caused by carbon release from permafrost thawing, The Cryosphere, 6, 1063-1076, doi:10.5194/tc6-1063-2012, 2012.

Camill, P.: Permafrost Thaw Accelerates in Boreal Peatlands During Late-20th Century Climate Warming, Clim. Change, 68, 135-152, doi:10.1007/s10584-005-4785-y, 2005.

Conrad, R., Klose, M., and Claus, P.: Pathway of methane formation in anoxic rice field soil and rice roots determined by 13C-stable isotope fractionation, Chemosphere, 47, 797-806, doi:10.1016/S0045-6535(02)00120-0, 2002.

Dankers, R., Burke, E. J., and Price, J.: Simulation of permafrost and seasonal thaw depth in the JULES land surface scheme, The Cryosphere, 5, 773-790, doi:10.5194/tc-5-773-2011, 2011.

Dutta, K., Schuur, E. A. G., Neff, J. C., and Zimov, S. A.: Potential carbon release from permafrost soils of Northeastern Siberia, Global Change Biol., 12, 2336-2351, 2006.

Ekici, A., Beer, C., Hagemann, S., Boike, J., Langer, M., and Hauck, C.: Simulating high-latitude permafrost regions by the JSBACH terrestrial ecosystem model, Geosci. Model Dev., 7, 631-647, doi:10.5194/gmd-7-631-2014, 2014.

Eliseev, A. V., Mokhov, I. I., Arzhanov, M. M., Demchenko, P. F., and Denisov, S. N.: Interaction of the methane cycle and pro- 
cesses in wetland ecosystems in a climate model of intermediate complexity, Izvestiya Atmos. Ocean. Phys., 44, 139-152, 2008.

Environmental Protection Agency (EPA): Methane and nitrous oxide emissions from natural sources EPA 430-R-10-001, US Environmental Protection Agency, Washington, DC, 1-194, 2010.

Frauenfeld, O. W., Zhang, T., Barry, R. G., and Gilichinsky, D.: Interdecadal changes in seasonal freeze and thaw depths in Russia, J. Geophys. Res.-Atmos., 109, D05101, doi:10.1029/2003JD004245, 2004.

Friedlingstein, P., Cox, P., Betts, R., Bopp, L., von Bloh, W., Brovkin, V., Cadule, P., Doney, S., Eby, M., Fung, I., Bala, G., John, J., Jones, C., Joos, F., Kato, T., Kawamiya, M., Knorr, W., Lindsay, K., Matthews, H. D., Raddatz, T., Rayner, P., Reick, C., Roeckner, E., Schnitzler, K.-G., Schnur, R., Strassmann, K., Weaver, K., Yoshikawa, C., and Zeng, N.: Climate-Carbon Cycle Feedback Analysis: Results from the C4MIP Model Intercomparison, J. Climate, 19, 3337-3353, doi:10.1175/JCLI3800.1, 2006.

Frolking, S., Roulet, N. T., Moore, T. R., Richard, P. J. H., Lavoie, M., and Muller, S. D.: Modeling northern peatland decomposition and peat accumulation, Ecosystems, 4, 479-498, 2001.

Gao, X., Schlosser, Sokolov, A., Walter Anthony, K., Zhuang, Q., and Kicklighter, D.: Permafrost degradation and methane: low risk of biogeochemical climate-warming feedback, Environ. Res. Lett., 8, 035014, doi:10.1088/1748-9326/8/3/035014, 2013.

Gouttevin, I., Menegoz, M., Dominé, F., Krinner, G., Koven, C., Ciais, P., Tarnocai, C., and Boike, J.: How the insulating properties of snow affect soil carbon distribution in the continental pan-Arctic area, J. Geophys. Res. Biogeosci., 117, G02020, doi:10.1029/2011JG001916, 2012.

Grosse, G., Schirrmeister, L., Siegert, C., Kunitsky, V. V., Slagoda, E. A., Andreev, A. A., and Dereviagyn, A. Y.: Geological and geomorphological evolution of a sedimentary periglacial landscape in Northeast Siberia during the Late Quaternary, Geomorphology, 86, 25-51, doi:10.1016/j.geomorph.2006.08.005, 2007.

Grosse, G., Harden, J., Turetsky, M., McGuire, A. D., Camill, P., Tarnocai, C., Frolking, S., Schuur, E. A. G., Jorgenson, T., Marchenko, S., Romanovsky, V., Wickland, K. P., French, N., Waldrop, M., Bourgeau-Chavez, L., and Striegl, R. G.: Vulnerability of high-latitude soil organic carbon in North America to disturbance, J. Geophys. Res., 116, G00K06, doi:10.1029/2010JG001507, 2011.

Harden, J. W., Koven, C. D., Ping, C.-L., Hugelius, G., David McGuire, A., Camill, P., Jorgenson, T., Kuhry, P., Michaelson, G. J., O’Donnell, J. A., Schuur, E. A. G., Tarnocai, C., Johnson, K., and Grosse, G.: Field information links permafrost carbon to physical vulnerabilities of thawing, Geophys. Res. Lett., 39, L15704, doi:10.1029/2012GL051958, 2012.

Hayes, D. J., Kicklighter, D. W., McGuire, A. D., Chen, M., Zhuang, Q., Yuan, F., Melillo, J. M., and Wullschleger, S. D.: The impacts of recent permafrost thaw on land-atmosphere greenhouse gas exchange, Environ. Res. Lett., 9, 045005, doi:10.1088/1748-9326/9/4/045005, 2014.

Hugelius, G., Tarnocai, C., Broll, G., Canadell, J. G., Kuhry, P., and Swanson, D. K.: The Northern Circumpolar Soil Carbon Database: spatially distributed datasets of soil coverage and soil carbon storage in the northern permafrost regions, Earth Syst. Sci. Data, 5, 3-13, doi:10.5194/essd-5-3-2013, 2013.
Hugelius, G., Strauss, J., Zubrzycki, S., Harden, J. W., Schuur, E. A. G., Ping, C. L., Schirrmeister, L., Grosse, G., Michaelson, G. J., Koven, C. D., O’Donnell, J. A., Elberling, B., Mishra, U., Camill, P., Yu, Z., Palmtag, J., and Kuhry, P.: Estimated stocks of circumpolar permafrost carbon with quantified uncertainty ranges and identified data gaps, Biogeosciences, 11, 6573-6593, doi:10.5194/bg-11-6573-2014, 2014.

Jafarov, E. E., Marchenko, S. S., and Romanovsky, V. E.: Numerical modeling of permafrost dynamics in Alaska using a high spatial resolution dataset, The Cryosphere, 6, 613-624, doi:10.5194/tc6-613-2012, 2012.

Johnson, K. D., Harden, J. W., McGuire, A. D., Clark, M., Yuan, F., and Finley, A. O.: Permafrost and organic layer interactions over a climate gradient in a discontinuous permafrost zone, Environ. Res. Lett., 8, 035028, doi:10.1088/1748-9326/8/3/035028, 2013.

Jones, B. M., Grosse, G., Arp, C. D., Jones, M. C., Walter Anthony, K. M., and Romanovsky, V. E.: Modern thermokarst lake dynamics in the continuous permafrost zone, northern Seward Peninsula, Alaska, J. Geophys. Res. Biogeosci., 116, G00M03, doi:10.1029/2011JG001666, 2011.

Jones, M. C., Grosse, G., Jones, B. M., and Walter Anthony, K.: Peat accumulation in drained thermokarst lake basins in continuous, ice-rich permafrost, northern Seward Peninsula, Alaska, J. Geophys. Res. Biogeosci., 117, G00M07, doi:10.1029/2011JG001766, 2012.

Jorgenson, M. T., Shur, Y. L., and Pullman, E. R.: Abrupt increase in permafrost degradation in Arctic Alaska, Geophys. Res. Lett., 33, L02503, doi:10.1029/2005GL024960, 2006.

Jorgenson, M. T., Romanovsky, V., Harden, J., Shur, Y., O’Donnell, J., Schuur, E. A. G., Kanevskiy, M., and Marchenko, S.: Resilience and vulnerability of permafrost to climate change, Canad. J. For. Res., 40, 1219-1236, 2010.

Kaufman, D. S., Ager, T. A., Anderson, N. J., Anderson, P. M., Andrews, J. T., Bartlein, P. J., Brubaker, L. B., Coats, L. L., Cwynar, L. C., Duvall, M. L., Dyke, A. S., Edwards, M. E., Eisner, W. R., Gajewski, K., Geirsdóttir, A., Hu, F. S., Jennings, A. E., Kaplan, M. R., Kerwin, M. W., Lozhkin, A. V., MacDonald, G. M., Miller, G. H., Mock, C. J., Oswald, W. W., Otto-Bliesner, B. L., Porinchu, D. F., Rühland, K., Smol, J. P., Steig, E. J., and Wolfe, B. B.: Holocene thermal maximum in the western Arctic (0-180 ${ }^{\circ}$ W), Quat. Sci. Rev., 23, 529-560, doi:10.1016/j.quascirev.2003.09.007, 2004.

Kessler, M. A., Plug, L. J., and Walter Anthony, K. M.: Simulating the decadal- to millennial-scale dynamics of morphology and sequestered carbon mobilization of two thermokarst lakes in NW Alaska, J. Geophys. Res. Biogeosci., 117, G00M06, doi:10.1029/2011JG001796, 2012.

Khvorostyanov, D. V., Ciais, P., Krinner, G., and Zimov, S. A.: Vulnerability of east Siberia's frozen carbon stores to future warming, Geophys. Res. Lett., 35, L10703, doi:10.1029/2008GL033639, 2008.

Kleinen, T., Brovkin, V., and Schuldt, R. J.: A dynamic model of wetland extent and peat accumulation: results for the Holocene, Biogeosciences, 9, 235-248, doi:10.5194/bg-9-235-2012, 2012.

Knoblauch, C., Beer, C., Sosnin, A., Wagner, D., Pfeiffer, E. M.: Predicting long-term carbon mineralization and trace gas production from thawing permafrost of Northeast Siberia, Global Change Biol., 19, 1160-1172, 2013. 
Kokelj, S. V., Lacelle, D., Lantz, T. C., Tunnicliffe, J., Malone, L., Clark, I. D., and Chin, K. S.: Thawing of massive ground ice in mega slumps drives increases in stream sediment and solute flux across a range of watershed scales, J. Geophys. Res.-Earth Surf., 118, 681-692, doi:10.1002/jgrf.20063, 2013.

Koven, C., Friedlingstein, P., Ciais, P., Khvorostyanov, D., Krinner, G., and Tarnocai, C.: On the formation of high-latitude soil carbon stocks: Effects of cryoturbation and insulation by organic matter in a land surface model, Geophys. Res. Lett., 36, L21501, doi:10.1029/2009GL040150, 2009.

Koven, C. D., Ringeval, B., Friedlingstein, P., Ciais, P., Cadule, P., Khvorostyanov, D., Krinner, G., and Tarnocai, C.: Permafrost carbon-climate feedbacks accelerate global warming, Proc. Natl. Acad. Sci., 108, 14769-14774, 2011.

Koven, C. D., Riley, W. J., and Stern, A.: Analysis of Permafrost Thermal Dynamics and Response to Climate Change in the CMIP5 Earth System Models, J. Climate, 26, 1877-1900, doi:10.1175/JCLI-D-12-00228.1, 2013a.

Koven, C. D., Riley, W. J., Subin, Z. M., Tang, J. Y., Torn, M. S., Collins, W. D., Bonan, G. B., Lawrence, D. M., and Swenson, S. C.: The effect of vertically resolved soil biogeochemistry and alternate soil $\mathrm{C}$ and $\mathrm{N}$ models on C dynamics of CLM4, Biogeosciences, 10, 7109-7131, doi:10.5194/bg-10-7109-2013, $2013 \mathrm{~b}$.

Krinner, G., and Boike, J.: A study of the large-scale climatic effects of a possible disappearance of high-latitude inland water surfaces during the 21st century, Boreal Environ. Res., 15, 203-217, 2010.

Langer, M., Westermann, S., Heikenfeld, M., Dorn, W., and Boike, J.: Satellite-based modeling of permafrost temperatures in a tundra lowland landscape, Remote Sens. Environ., 135, 12-24, doi:10.1016/j.rse.2013.03.011, 2013.

Laurion, I., Vincent, W. F., MacIntyre, S., Retamal, L., Dupont, C.,Francus, P., and Pienitz, R.: Variability in greenhouse gas emissions from permafrost thaw ponds, Limnol. Oceanogr., 55, 115-133, 2010.

Lawrence, D. M. and Slater, A. G.: Incorporating organic soil into a global climate model, Clim. Dynam., 30, 145-160, 2008.

Lawrence, D. M., Oleson, K. W., Flanner, M. G., Thornton, P. E., Swenson, S. C., Lawrence, P. J., Zeng, X., Yang, Z.-L., Levis, S., Sakaguchi, K., Bonan, G. B., and Slater, A. G.: Parameterization improvements and functional and structural advances in Version 4 of the Community Land Model, J. Adv. Model. Earth Syst., 3, M03001, doi:10.1029/2011ms000045, 2011.

Lee, H., Schuur, E. A. G., Inglett, K. S., Lavoie, M., and Chanton, J. P.: The rate of permafrost carbon release under aerobic and anaerobic conditions and its potential effects on climate, Global Change Biol., 18, 515-527, doi:10.1111/j.13652486.2011.02519.x, 2012.

Ling, F.: Numerical simulation of permafrost thermal regime and talik development under shallow thaw lakes on the Alaskan Arctic Coastal Plain, J. Geophys. Res., 108, 4511-4511, 2003.

Ling, F., Wu, Q., Zhang, T., and Niu, F.: Modelling Open-Talik Formation and Permafrost Lateral Thaw under a Thermokarst Lake, Beiluhe Basin, Qinghai-Tibet Plateau, Permafrost Periglacial. Proc., 23, 312-321, doi:10.1002/ppp.1754, 2012.

MacDougall, A. H., Avis, C. A., and Weaver, A. J.: Significant contribution to climate warming from the permafrost carbon feedback, Nature Geosci., 5, 719-721, 2012.
Mack, M. C., Schuur, E. A. G., Bret-Harte, M. S., Shaver, G. R., and Chapin, F. S.: Ecosystem carbon storage in arctic tundra reduced by long-term nutrient fertilization, Nature, 431, 440-443, 2004.

Marcott, S. A., Shakun, J. D., Clark, P. U., and Mix, A. C.: A Reconstruction of Regional and Global Temperature for the Past 11,300 Years, Science, 339, 1198-1201, doi:10.1126/science.1228026, 2013.

Mishra, U., Jastrow, J. D., Matamala, R., Hugelius, G., Koven, C. D., Harden, J. W., Ping, C. L., Michaelson, G. J., Fan, Z., Miller, R. M., McGuire, A. D., Tarnocai, C., Kuhry, P., Riley, W. J., Schaefer, K., Schuur, E. A. G., Jorgenson, M. T., and Hinzman, L. D.: Empirical estimates to reduce modeling uncertainties of soil organic carbon in permafrost regions: a review of recent progress and remaining challenges, Environ. Res. Lett., 8, 035020, doi:10.1088/1748-9326/8/3/035020, 2013.

Morgenstern, A., Grosse, G., Günther, F., Fedorova, I., and Schirrmeister, L.: Spatial analyses of thermokarst lakes and basins in Yedoma landscapes of the Lena Delta, The Cryosphere, 5, 849-867, doi:10.5194/tc-5-849-2011, 2011.

Myhre, G., Highwood, E. J., Shine, K. P., and Stordal, F.: New estimates of radiative forcing due to well mixed greenhouse gases, Geophys. Res. Lett., 25, 2715-2718, 1998.

Olefeldt, D., Turetsky, M. R., Crill, P. M., and McGuire, A. D.: Environmental and physical controls on northern terrestrial methane emissions across permafrost zones, Global Change Biol., 19, 589-603, doi:10.1111/gcb.12071, 2013.

Osterkamp, T. E.: Causes of warming and thawing permafrost in Alaska, Eos, Transactions American Geophysical Union, 88, 522-523, doi:10.1029/2007EO480002, 2007.

Plug, L. J. and West, J. J.: Thaw lake expansion in a twodimensional coupled model of heat transfer, thaw subsidence, and mass movement, J. Geophys. Res.-Earth Surf., 114, F01002, doi:10.1029/2006JF000740, 2009.

Raynolds, M. K., Walker, D. A., Ambrosius, K. J., Brown, J., Everett, K. R., Kanevskiy, M., Kofinas, G. P., Romanovsky, V. E., Shur, Y., and Webber, P. J.: Cumulative geoecological effects of 62 years of infrastructure and climate change in ice-rich permafrost landscapes, Prudhoe Bay Oilfield, Alaska, Global Change Biol., 20, 1211-1224, doi:10.1111/gcb.12500, 2014.

Romanovsky, V. E., Smith, S. L., and Christiansen, H. H.: Permafrost thermal state in the polar Northern Hemisphere during the international polar year 2007-2009: a synthesis, Permafrost Periglacial. Proc., 21, 106-116, doi:10.1002/ppp.689, 2010.

Sannel, A. B. K. and Kuhry, P.: Warming-induced destabilization of peat plateau/thermokarst lake complexes, J. Geophys. Res. Biogeosci., 116, G03035, doi:10.1029/2010JG001635, 2011.

Scanlon, D. and Moore, T.: Carbon dioxide production from peatland soil profiles: The influence of temperature, oxic/anoxic conditions and substrate, Soil Science, 165, 153-160, 2000.

Schädel, C., Schuur, E. A. G., Bracho, R., Elberling, B., Knoblauch, C., Lee, H., Luo, Y., Shaver, G. R., and Turetsky, M. R.: Circumpolar assessment of permafrost $\mathrm{C}$ quality and its vulnerability over time using long-term incubation data, Global Change Biol., 20, 641-652, doi:10.1111/gcb.12417, 2014.

Schaefer, K., Lantuit, H., Romanovsky, V. E., Schuur, E. A. G., and Witt, R.: The impact of the permafrost carbon feedback on global climate, Environ. Res. Lett., 9, 085003, doi:10.1088/17489326/9/8/085003, 2014. 
Schaphoff, S., Heyder, U., Ostberg, S., Gerten, D., Heinke, J., and Lucht, W.: Contribution of permafrost soils to the global carbon budget, Environ. Res. Lett., 8, 014026, doi:10.1088/17489326/9/8/085003, 2013.

Schirrmeister, L., Grosse, G., Wetterich, S., Overduin, P. P., Strauss, J., Schuur, E. A. G., and Hubberten, H.-W.: Fossil organic matter characteristics in permafrost deposits of the northeast Siberian Arctic, J. Geophys. Res. Biogeosci., 116, G00M02, doi:10.1029/2011JG001647, 2011.

Schmidt, M. W. I., Torn, M. S., Abiven, S., Dittmar, T., Guggenberger, G., Janssens, I. A., Kleber, M., Kogel-Knabner, I., Lehmann, J., Manning, D. A. C., Nannipieri, P., Rasse, D. P., Weiner, S., and Trumbore, S. E.: Persistence of soil organic matter as an ecosystem property, Nature, 478, 49-56, 2011.

Schneider von Deimling, T., Meinshausen, M., Levermann, A., Huber, V., Frieler, K., Lawrence, D. M., and Brovkin, V.: Estimating the near-surface permafrost-carbon feedback on global warming, Biogeosciences, 9, 649-665, doi:10.5194/bg-9-649-2012, 2012.

Schuur, E. A. G., Bockheim, J., Canadell, J. G., Euskirchen, E., Field, C. B., Goryachkin, S. V., Hagemann, S., Kuhry, P., Lafleur, P. M., Lee, H., Mazhitova, G., Nelson, F. E., Rinke, A., Romanovsky, V. E., Shiklomanov, N., Tarnocai, C., Venevsky, S., Vogel, J. G., and Zimov, S. A.: Vulnerability of permafrost carbon to climate change: Implications for the global carbon cycle, Bioscience, 58, 701-714, 2008.

Schuur, E. A. G., Abbott, B. W., Bowden, W. B., Brovkin, V., Camill, P., Canadell, J. G., Chanton, J. P., Chapin, F. S., III, Christensen, T. R., Ciais, P., Crosby, B. T., Czimczik, C. I., Grosse, G., Harden, J., Hayes, D. J., Hugelius, G., Jastrow, J. D., Jones, J. B., Kleinen, T., Koven, C. D., Krinner, G., Kuhry, P., Lawrence, D. M., McGuire, A. D., Natali, S. M., O’Donnell, J. A., Ping, C. L., Riley, W. J., Rinke, A., Romanovsky, V. E., Sannel, A. B. K., Schädel, C., Schaefer, K., Sky, J., Subin, Z. M., Tarnocai, C., Turetsky, M. R., Waldrop, M. P., Walter Anthony, K. M., Wickland, K. P., Wilson, C. J., and Zimov, S. A.: Expert assessment of vulnerability of permafrost carbon to climate change, Clim. Change, 119, 359-374, doi:10.1007/s10584-013-0730-7, 2013.

Schuur, E. A. G., McGuire, A. D., Schadel, C., Grosse, G., Harden, J. W., Hayes, D. J., Hugelius, G., Koven, C. D., Kuhry, P., Lawrence, D. M., Natali, S. M., Olefeldt, D., Romanovsky, V. E., Schaefer, K., Turetsky, M. R., Treat, C. C., and Vonk, J. E.: Climate change and the permafrost carbon feedback, Nature, 520, 171-179, doi:10.1038/nature14338, 2015.

Segers, R.: Methane production and methane consumption: a review of processes underlying wetland methane fluxes, Biogeochemistry, 41, 23-51, 1998.

Shakhova, N., Semiletov, I., Salyuk, A., Yusupov, V., Kosmach, D., and Gustafsson, O.: Extensive Methane Venting to the Atmosphere from Sediments of the East Siberian Arctic Shelf, Science, 327, 1246-1250, 2010.

Shindell, D. T., Faluvegi, G., Koch, D. M., Schmidt, G. A., Unger, N., and Bauer, S. E.: Improved Attribution of Climate Forcing to Emissions, Science, 326, 716-718, doi:10.1126/science.1174760, 2009.

Sitch, S., Smith, B., Prentice, I. C., Arneth, A., Bondeau, A., Cramer, W., Kaplan, J. O., Levis, S., Lucht, W., Sykes, M. T., Thonicke, K., and Venevsky, S.: Evaluation of ecosystem dynamics, plant geography and terrestrial carbon cycling in the LPJ dynamic global vegetation model, Global Change Biol., 9, 161$185,2003$.

Slater, A. G. and Lawrence, D. M.: Diagnosing Present and Future Permafrost from Climate Models, J. Climate, 26, 5608-5623, doi:10.1175/JCLI-D-12-00341.1, 2013.

Smith, L. C., Sheng, Y., MacDonald, G. M., and Hinzman, L. D.: Disappearing arctic lakes, Science, 308, 1429-1429, 2005.

Stieglitz, M., Déry, S. J., Romanovsky, V. E., and Osterkamp, T. E.: The role of snow cover in the warming of arctic permafrost, Geophys. Res. Lett., 30, 1721, doi:10.1029/2003GL017337, 2003.

Strauss, J., Schirrmeister, L., Wetterich, S., Borchers, A., and Davydov, S. P.: Grain-size properties and organic-carbon stock of Yedoma Ice Complex permafrost from the Kolyma lowland, northeastern Siberia, Global Biogeochem. Cy., 26, GB3003, doi:10.1029/2011GB004104, 2012.

Strauss, J., Schirrmeister, L., Grosse, G., Wetterich, S., Ulrich, M., Herzschuh, U., and Hubberten, H.-W.: The deep permafrost carbon pool of the Yedoma region in Siberia and Alaska, Geophys. Res. Lett., 40, 6165-6170, doi:10.1002/2013GL058088, 2013.

Strauss, J., Schirrmeister, L., Mangelsdorf, K., Eichhorn, L., Wetterich, S., and Herzschuh, U.: Organic matter quality of deep permafrost carbon - a study from Arctic Siberia, Biogeosciences, 12, 2227-2245), doi:10.5194/bg-12-2227-2015, 2015.

Taylor, K. E., Stouffer, R. J., and Meehl, G. A.: An Overview of CMIP5 and the Experiment Design, B. Am. Meteor. Soc., 93, 485-498, doi:10.1175/BAMS-D-11-00094.1, 2011.

Turetsky, M. R., Kane, E. S., Harden, J. W., Ottmar, R. D., Manies, K. L., Hoy, E., and Kasischke, E. S.: Recent acceleration of biomass burning and carbon losses in Alaskan forests and peatlands, Nature Geosci., 4, 27-31, 2011.

van Huissteden, J. and Dolman, A.: Soil carbon in the Arctic and the permafrost carbon feedback, Current Op. Environ. Sustain., 4, 545-551, 2012.

van Huissteden, J., Berrittella, C., Parmentier, F. J. W., Mi, Y., Maximov, T. C., and Dolman, A. J.: Methane emissions from permafrost thaw lakes limited by lake drainage, Nature Clim. Change, 1, 119-123, 2011.

Velichko, A. A., Catto, N., Drenova, A. N., Klimanov, V. A., Kremenetski, K. V., and Nechaev, V. P.: Climate changes in East Europe and Siberia at the Late glacial-holocene transition, Quat. Int., 91, 75-99, doi:10.1016/S1040-6182(01)00104-5, 2002.

Walter Anthony, K. M., Anthony, P., Grosse, G., and Chanton, J.: Geologic methane seeps along boundaries of Arctic permafrost thaw and melting glaciers, Nature Geosci., 5, 419-426, 2012.

Walter Anthony, K. M., Zimov, S. A., Grosse, G., Jones, M. C., Anthony, P. M., Iii, F. S. C., Finlay, J. C., Mack, M. C., Davydov, S., Frenzel, P., and Frolking, S.: A shift of thermokarst lakes from carbon sources to sinks during the Holocene epoch, Nature, 511, 452-456, doi:10.1038/nature13560, 2014.

Walter, B. P. and Heimann, M.: A process-based, climate-sensitive model to derive methane emissions from natural wetlands: Application to five wetland sites, sensitivity to model parameters, and climate, Global Biogeochem. Cycles, 14, 745-765, 2000.

Walter, K. M., Edwards, M. E., Grosse, G., Zimov, S. A., and Chapin, F. S.: Thermokarst lakes as a source of atmospheric methane during the last deglaciation, Science, 318, 633-636, 2007a.

Walter, K. M., Smith, L. C., and Chapin, F. S.: Methane bubbling from northern lakes: present and future contributions to 
the global methane budget, Phil. Trans. Roy. Soc. A-Math. Phys. Eng. Sci., 365, 1657-1676, 2007b.

Wisser, D., Marchenko, S., Talbot, J., Treat, C., and Frolking, S.: Soil temperature response to 21 st century global warming: the role of and some implications for peat carbon in thawing permafrost soils in North America, Earth Syst. Dynam., 2, 121-138, doi:10.5194/esd-2-121-2011, 2011.

Yi, S., Wischnewski, K., Langer, M., Muster, S., and Boike, J.: Freeze/thaw processes in complex permafrost landscapes of northern Siberia simulated using the TEM ecosystem model: impact of thermokarst ponds and lakes, Geosci. Model Dev., 7, 1671-1689, doi:10.5194/gmd-7-1671-2014, 2014.

Yoshikawa, K., and Hinzman, L. D.: Shrinking thermokarst ponds and groundwater dynamics in discontinuous permafrost near council, Alaska, Permafrost Periglacial. Proc., 14, 151-160, doi:10.1002/ppp.451, 2003.
Zimov, S. A., Davydov, S. P., Zimova, G. M., Davydova, A. I., Schuur, E. A. G., Dutta, K., and Chapin, F. S.: Permafrost carbon: Stock and decomposability of a globally significant carbon pool, Geophys. Res. Lett., 33, L20502, doi:10.1029/2006GL027484, 2006.

Zhang, T., Frauenfeld, O. W., and Barry, R. G.: Time series of active layer thickness in the Russian Arctic, 1930-1990, Digital media, National Snow and Ice Data Center, Boulder, CO, available at: http://nsidc.org/data/arcss160.html (last access: 3 June 2015), 2006. 